\title{
Synoptic patterns of atmospheric circulation associated with intense precipitation events over the Brazilian Amazon
}

\author{
Eliane Barbosa Santos ${ }^{1}$ Paulo Sérgio Lucio ${ }^{1}$ - Cláudio Moisés Santos e Silva ${ }^{1}$
}

Received: 19 June 2015 / Accepted: 16 December 2015

(C) Springer-Verlag Wien 2015

\begin{abstract}
The objective of this study is to characterize the atmospheric patterns associated with the occurrence of intense precipitation events (IPE) in different sub-regions of the Brazilian Amazon. Intense rainfall cases over six subregions were selected from a precipitation data set for the period from 1983 to 2012. The composition technique was used to characterize the prevailing atmospheric patterns for the occurrence of IPE. In the south of the Amazon, the composition fields showed a favorable configuration for the formation of the South Atlantic Convergence Zone (SACZ). Along the coast, the intense precipitation events must be associated with mesoscale systems, such as squall lines. In the northwest, they are apparently associated with the Intertropical Convergence Zone (ITCZ) and/or local convection. The results reveal the complexity of the synoptic environment associated with the formation and development of weather systems that produce heavy rainfall in the Amazon Basin. Several factors can interfere as conditions in largescale, local conditions and thermodynamic factors.
\end{abstract}

\section{Introduction}

The Brazilian Amazon has different weather and climate characteristics due to its extensive territorial range $\left(5^{\circ} \mathrm{N}-18^{\circ} \mathrm{S}\right.$ and $42^{\circ} \mathrm{W}-74^{\circ} \mathrm{W}$ ), allowing the identifying of different subregions (Santos et al. 2014). These differences are related to

Eliane Barbosa Santos

elianbs@gmail.com

1 Programa de Pós-graduação em Ciências Climáticas, Universidade Federal do Rio Grande do Norte, Campus Universitário Lagoa nova, caixa postal 1524, Natal, RN 59078-970, Brazil topographic effects and to the effect of weather systems that operate at different time scales. In addition, they are modulated by interaction mechanisms on the ocean-atmosphere interface, which can promote rainfall totals above and/or below the climatological mean (De Souza et al. 2005a).

The rainfall regime in the Amazon region is influenced by two main precipitating systems on the synoptic scale: the Intertropical Convergence Zone (ITCZ) and the South Atlantic Convergence Zone (SACZ). The ITCZ is part of the general circulation of the atmosphere and appears at the ascending branch of atmospheric Hadley cells. The convergence of inter-hemisphere trade winds leads to strong convective cloud systems, heavy precipitation, and intense latent-heat release within the ITCZ (Hastenrath 1985; Curtis and Hastenrath 1999). It is the main system which modulates rainfall variability in the Amazon coast that is responsible for the maximum precipitation during the austral autumn (De Souza et al. 2005b; De Souza and Rocha 2006). In the austral winter, the ITCZ moves to the north, taking the strong convective activities with it to those regions (De Souza and Rocha 2006; Chen et al. 2008; De Souza et al. 2009; M Moura and Vitorino 2012). Hence, the austral winter is the driest season in a large part of the Amazon. The SACZ also has an important role in rainfall in the region where it operates. Its main feature is the high-variability convective positioned east of the Andes Mountains with northwest-southeast direction, from the south of the Amazon to the South Atlantic (Carvalho et al. 2002, 2004).

The extensive cloudiness band of SACZ produces large increments of precipitation over southeastern Brazil and southern and southwestern Amazon region in late spring and austral summer (Carvalho et al. 2004; Grimm 2011; de Quadro et al. 2012; De Oliveira et al. 2013). Frequently, parts of this system drift northward, resulting in increased rainfall over eastern Amazonia. The occurrence of a coupling of 
SACZ with ITCZ is common during these episodes, in association with systems such as the Bolivian High and cyclonic vortices at high levels, which can cause widespread rainfall and lightning storms over much of eastern Amazonia (Gan and Kousky 1986; Souza and Ambrizzi 2003).

On the mesoscale, the activity of the Coastal Squall Lines (CSL) stand out, which are more frequent in the winter and austral autumn (Cohen et al. 1995; Alcântara et al. 2011). The topography and local circulation such as breeze circulation and river breeze are also important in study region, which may increase the activity of convective systems that can produce large increments of precipitation and severe weather in a few hours under favorable atmospheric conditions (Oliveira and Fitzjarrald 1993; Silva Dias et al. 2004).

The main mechanisms of tropical ocean-atmosphere circulation, which can affect rainfall anomalies in this region, are the El Niño Southern Oscillation over the Pacific Ocean and the interhemispheric meridional gradient of sea surface temperatures anomalies over the Atlantic Ocean (Nobre and Shukla 1996; De Souza et al. 2000; Liebmann and Marengo 2001). Such mechanisms act in different phases favoring or disfavoring convective activity in tropical areas (De Souza et al. 2005). The Madden-Julian Oscillation, dominant mode of intraseasonal variability in the tropical atmosphere (Madden and Julian 1972), can also have important effects on the local precipitation (De Souza and Rocha 2006). Souza and Ambrizzi (2006) studied the precipitation modulation in Brazil and detected that this intraseasonal oscillation is responsible for rain increasing in the Amazon forest, and that it interacts with the systems responsible for the sub-monthly variation of SACZ and of ITCZ.

In the last decades, extreme events, increasingly more frequent and intense, have manifested both in rural and urban areas in the study region (Marengo et al. 2011, 2012, 2013a, 2013b, Marengo and Espinoza 2015; Espinoza et al. 2014). These events have produced impacts such as floods and inundations, affecting human and natural systems (Marengo et al. 2012, 2013b; Espinoza et al. 2011, 2012, 2013, 2014). The expectations these extremes continue in the future are high, even taking into account the uncertainties (Marengo et al. 2013b). In 2014 and 2015, two states of the Brazilian Amazon, Acre and Rondônia, declared state of calamity due to floods caused by heavy rainfall in the headwaters of the rivers, Rio Acre and Rio Madeira. In 2014, rainfall was about 80-100 \% above normal in the area (Espinoza et al. 2014). As such, studies related to atmospheric circulation and the occurrence of intense precipitation events (IPE) are essential to monitor the climate and predict the weather. Such studies could be used as a source of information for socio-economic measures. In this context, this study seeks to characterize the prevailing atmospheric patterns for the occurrence of IPE in the sub-regions of the Brazilian Amazon.

\section{Materials and methods}

\subsection{Datasets}

The daily rainfall dataset for the period 1983-2012 was obtained from the National Water Agency (Agência Nacional de Água - ANA) and Meteorological Database for Education and Research (Banco de Dados Meteorológicos para Ensino e Pesquisa - BDMEP) of the National Institute of Meteorology (Instituto Nacional de Meteorologia - INMET). The stations were selected following the recommendations of the World Meteorological Organization (WMO), established in Technical Document WMO-TD/No. 341. This document recommends to (i) discard all months showing any missing daily values and (ii) discard monthly series (climatological normal) that present 3 or more consecutive months missing or more than 5 alternate months missing. In the initial set, 1129 rain gauges were included, but only 305 were used in our study, following the WMO recommendations.

To characterize the atmospheric patterns associated with IPE, the daily re-analysis data of the ERA-Interim project of the European Center for Medium-Range Weather Forecasts (ECMWF) were used (Dee et al. 2011). We employed the following meteorological variables: zonal wind, meridional wind, geopotential, vertical velocity (omega), and specific humidity for the period from 1983 to 2012, with a grid spacing of $1.5^{\circ}$ latitude $\times 1.5^{\circ}$ longitude .

\subsection{Methods}

\subsubsection{The intense precipitation events}

The IPE were defined for the homogeneous rainfall regions of the Brazilian Amazon established by Santos et al. (2014). These authors used Ward's hierarchical agglomerative method as a measure of similarity to Euclidian distance and identified six homogeneous rainfall regions (Fig. 1): two sub-regions in the south and four sub-regions in the north, with two being coastal regions and two in the northwest portion. According to the authors, these sub-regions are sufficient to represent different standards and intensities of precipitation in the Brazilian Amazon. In this study, these sub-regions are represented by synthetic precipitation series, which comprise the daily maximum values of each sub-region, i.e., the synthetic series were formed by data from different stations for different days. 


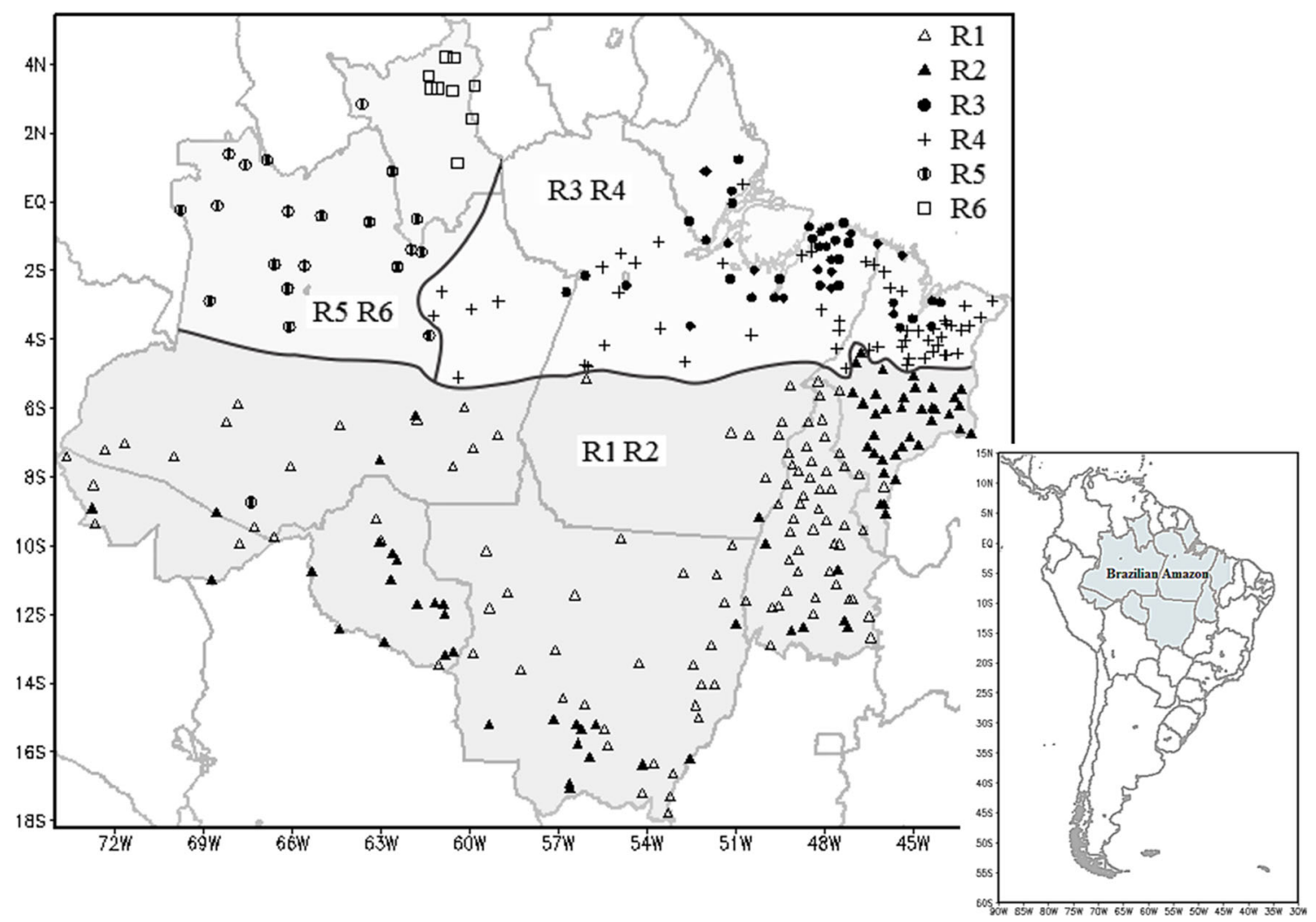

Fig. 1 Spatial distribution of stations used in this study, for the six homogeneous rainfall regions of the Brazilian Amazon (R1, R2, R3, R4, R5, and R6). Source: Adapted from Santos et al. (2014)

The IPE were defined based on the calculation of precipitation distribution percentiles, which is a method used in several meteorology studies (Groisman et al. 2005; Zhai et al. 2005; Gemmer et al. 2011; Oliveira et al. 2013, among others). An IPE is therefore defined as a rainfall event above the 95th percentile. IPE were selected according to the following criteria: (i) the IPE occurred simultaneously in the two sub-regions of each region, south (R1 and R2), coast (R3 and R4), and northwest (R5 and R6) of the Amazon; (ii) precipitation $(\geq 0.1 \mathrm{~mm}$ ) was recorded in more than $50 \%$ of the stations belonging to each region on the same day.

After selecting the IPE for each region, the events were separated by season of the year: austral summer (December, January, and February - DJF); austral autumn (March, April, and May - MAM); austral winter (June, July, and August JJA); and austral spring (September, October, and November SON).

\subsubsection{Composition of anomalies}

For the season with the highest occurrence of IPE, anomaly composites for the day of the event-D $(0)$, and for the three $\mathrm{D}(-3)$ and six $\mathrm{D}(-6)$ preceding days, for each region were calculated. At low and high levels, anomaly composites of geopotential height and wind were calculated. At medium levels, anomaly composites of geopotential height and omega were calculated. In addition to the anomalies of these variables, at low levels, the composition of moisture flux divergence was calculated. Negative values indicate moisture convergence and positive values indicate moisture divergence. Negative values indicate moisture convergence and positive values indicate moisture divergence. In this study, only the convergence was shown in the composition and the values multiplied by -1 . Thus, positive values indicate moisture convergence.

The composition technique was used because of its efficiency in identifying the mean standards and the main characteristics associated with a particular weather phenomenon. The composition of anomaly fields for each variable was obtained in a way similar to Lima et al. (2010) and Lima and Satyamurty (2010), as follows:

$\bar{\Phi}(x, y, z, D-n)=\frac{1}{N} \sum_{j=i}^{N} \Phi(x, y, z, j, D-n)$

where $\Phi$ is the variable of the compound; $(x, y, z)$ indicates the spatial position of the variable; $N$ is the number of cases identified during the study period, $D-n$ is the $n$th day preceding the event $(n=0,1,2,3)$, and the suffix $j$ 
refers to the $j$ th event.

Considering $\Phi_{c}(x, y, z)$ the climatology of variable $\Phi$, the anomaly fields of the composition $\Phi_{\mathrm{AC}}$ will be obtained as follows:

$\Phi_{\mathrm{AC}}(x, y, z, D-n)=\bar{\Phi}(x, y, z, D-n)-\Phi_{c}(x, y, z)$

The statistical significance for each composition is assessed through the application of Student's $t$ test. The composition maps are plotted in such a way as to highlight the anomalies that exceed the level of significance of $5 \%$ according to the $t$ test. This occurs when

$\Phi_{\mathrm{AC}} \geq \frac{t_{95 \%} \cdot \sigma}{\sqrt{N}}$

If the anomaly of the composition $\left(\Phi_{\mathrm{AC}}\right)$ is to be accepted at the level of significance of $5 \%$, then it must be greater than or equal to $\frac{t_{95 \%} \cdot \sigma}{\sqrt{N}}$, where $N$ is the number of events used in each composition, $\sigma$ is the standard deviation, and $t_{95 \%}$ is the value set by Student's $t$ test at the level of confidence of $95 \%$.

\section{Results and discussion}

\subsection{The frequency of intense precipitation events}

Using the criterion described earlier, 59, 124, and 26 cases of IPE were selected for the regions of the south, coast, and northwest of the Amazon, respectively (Fig. 2a).

The northwest was the region with the lowest number of selected cases because the rainy season appears in different months in its sub-regions (R5 and R6). R5 has high rainfall throughout the year, with more intense values in MAM. The R6 (northwest, State of Roraima) region is located in the northern hemisphere; it has the climate characteristics of the northern hemisphere, with its rainy season in JJA. As such, in the northwest, the IPE were more frequent in JJA, with 11

Fig. 2 a Number of cases selected in each region: south (R1, R2); coast (R3, R4); and northwest (R5, R6). b Percentage of the number of cases separated by season of the year (a)

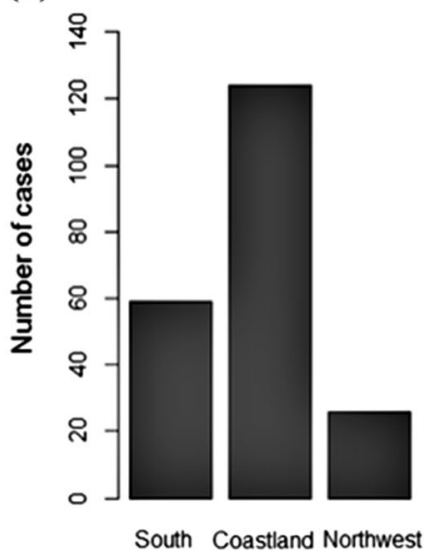

(42.3\%) cases and daily precipitation totals between 70.6 and $161.6 \mathrm{~mm}$.

In general, the highest occurrence of IPE was observed during the time of the rainy season in the respective regions (Fig. 2b). In the south of the Amazon, the highest occurrence was recorded in DJF, with 34 (57.6\%) identified cases and daily precipitation totals between 101.4 and $190.0 \mathrm{~mm}$. On the coast, the highest occurrence was in MAM, with 74 (59.7\%) cases and daily precipitation totals between 104.2 and $277.0 \mathrm{~mm}$. These results are consistent with Santos et al. (2015), who studied the return period of extreme daily precipitation events in the six sub-regions of the Brazilian Amazon and found that extremes of more intense rainfall occurred during the rainy or transitional seasons of each sub-region.

\subsection{Atmospheric characteristics at low levels}

The composition maps were plotted in such a way as to highlight the anomalies that exceed the level of significance of $5 \%$. For this, shaded areas were plotted, representing significant areas at the level of confidence of $95 \%$. This value means that the study assumed a probability of only $5 \%$ that differences between the atmospheric patterns during the occurrence of IPE are found. Thus, in the shaded areas, the atmospheric patterns during the occurrence of IPE are the same, with level of confidence of $95 \%$.

Anomalies compositions at $850 \mathrm{hPa}$ associated with IPE in the south of the Amazon are presented in Fig. 3. For the geopotential anomalies (Fig. 3a), large areas of significant negative anomalies with values between -100 and $-300 \mathrm{gpm}$ can be observed, with a center around $45^{\circ} \mathrm{W}$ and $25^{\circ} \mathrm{S}$. The main difference between $\mathrm{D}(-6), \mathrm{D}(-3)$, and $\mathrm{D}(0)$ is the intensity and the configuration of significant positive anomalies, which is clearly configured in $\mathrm{D}(-6)$ with a center around $28^{\circ} \mathrm{W}$ and $45^{\circ} \mathrm{S}$ of $400 \mathrm{gpm}$. In $\mathrm{D}(-3)$ and $\mathrm{D}(0)$, these positive anomalies are weaker and less clearly defined.

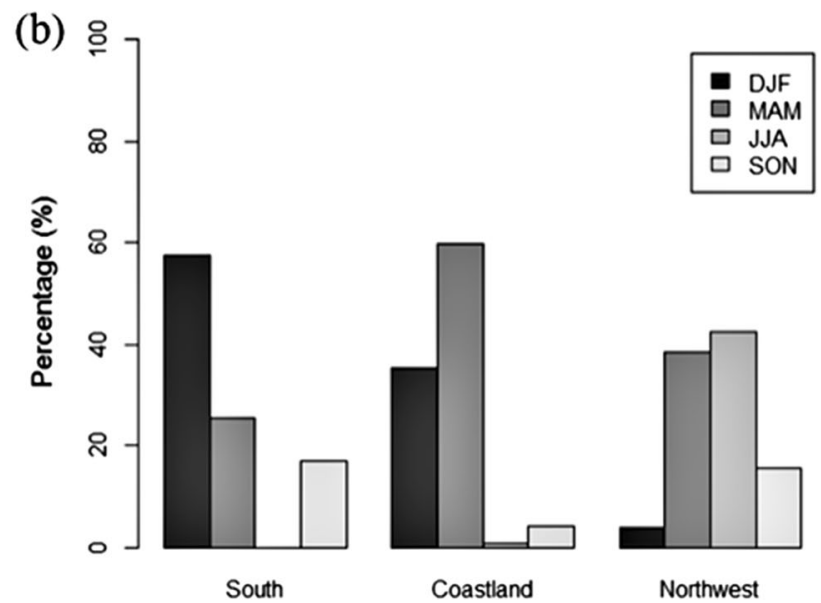


(a)
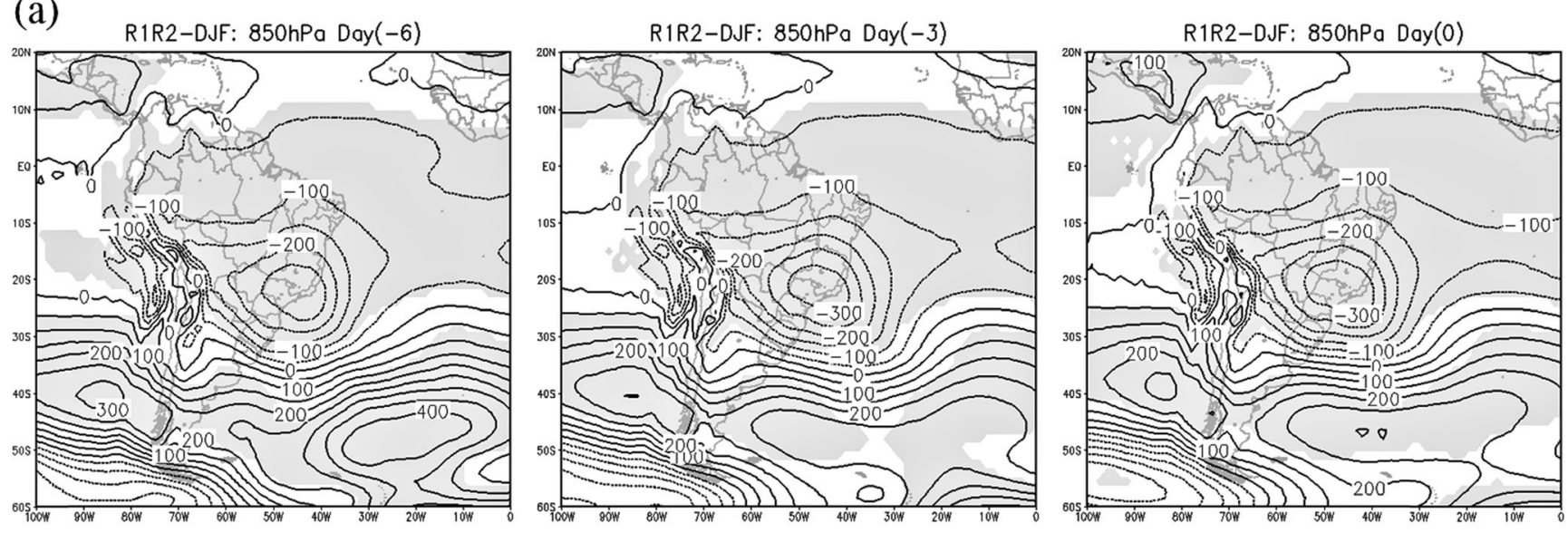

(b)
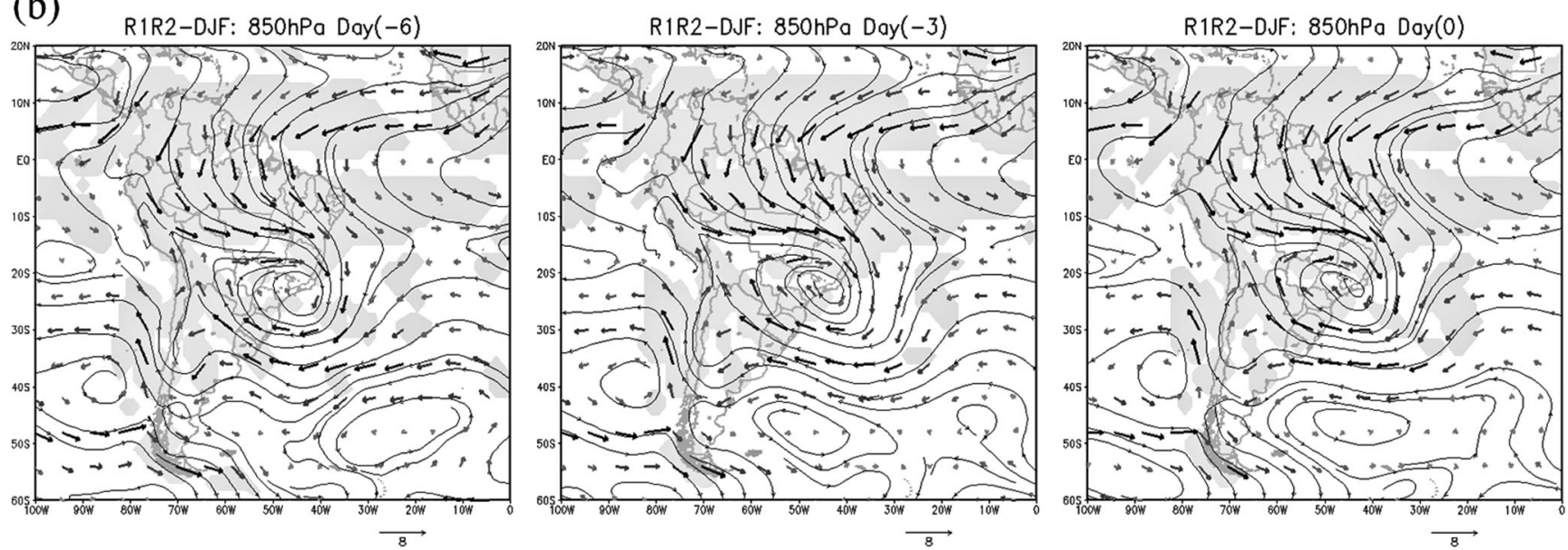

(c)
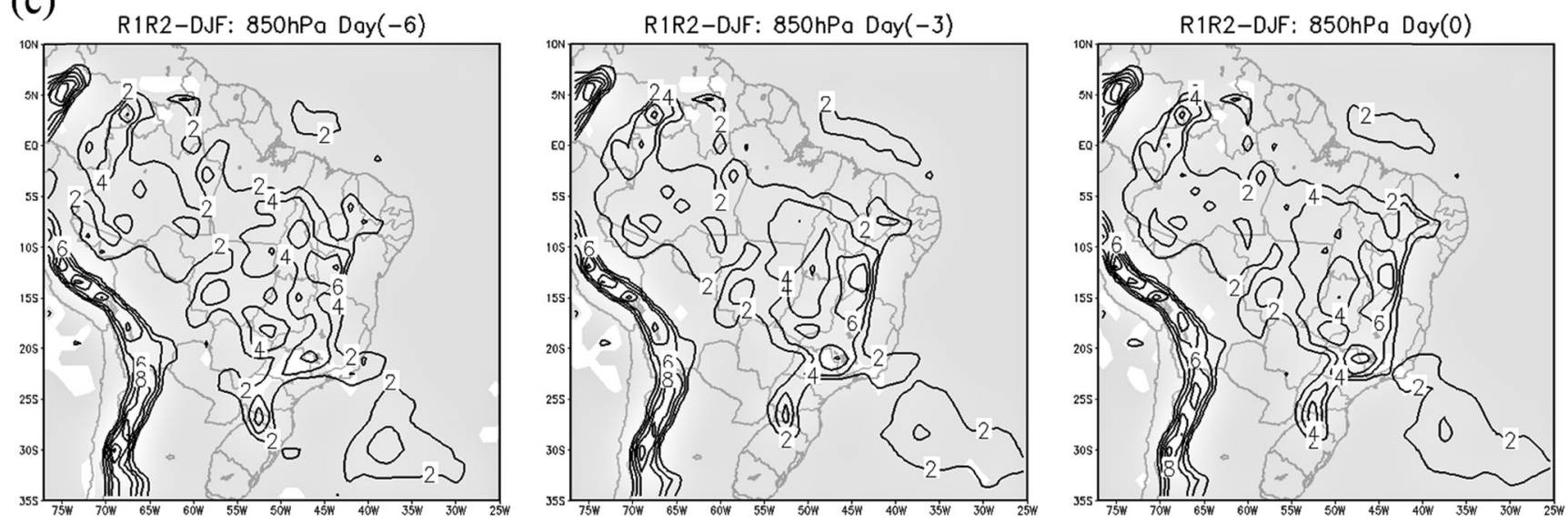

Fig. 3 Composition of anomalies for the south of the Amazon at $850 \mathrm{hPa}$, in the austral summer (DJF), for $\mathrm{D}(-6), \mathrm{D}(-3)$, and $\mathrm{D}(0)$ : a vector winds anomalies; c moisture convergence $\left(10^{5} \mathrm{~g} / \mathrm{kg} / \mathrm{s}\right)$. The geopotential anomalies (gpm, interval of $50 \mathrm{gpm})$; $\mathbf{b}$ current lines and

shaded areas are significant at the level of confidence of $95 \%$

Anomalous cyclonic circulation influences the negative geopotential anomalies, and the positive anomalies are influenced by anomalous anticyclonic circulation (Fig. 3b). In the lower troposphere, the trade winds come from the Tropical Atlantic. They cross the Amazon, moving counter-clockwise toward the east of the Andes Mountains near the south and southeast at $15^{\circ} \mathrm{S}$, where the flow becomes cyclonic in the central parts of the continent, forming a low close to $20^{\circ} \mathrm{S}$ (Nobre et al. 2009), as can be seen in Fig. 3b. This cyclonic circulation is significant at $5 \%$. The cyclonic circulation favors the formation of the SACZ, a typical 
austral summer (DJF) phenomenon in South America that plays a leading role in the rainfall regime of the regions where it is active, causing high rainfall values. As ascending air in the region of the SACZ cools and becomes denser, part of this volume of cold air descends on the periphery (subsidence), forcing the development of a high-pressure area at the surface. This explains the formation of the insignificant anomalous anticyclone circulation to the south of the cyclonic circulation.

In Fig. 3b, the winds come from the west in the southwest of the Amazon, which is characteristic of (a)

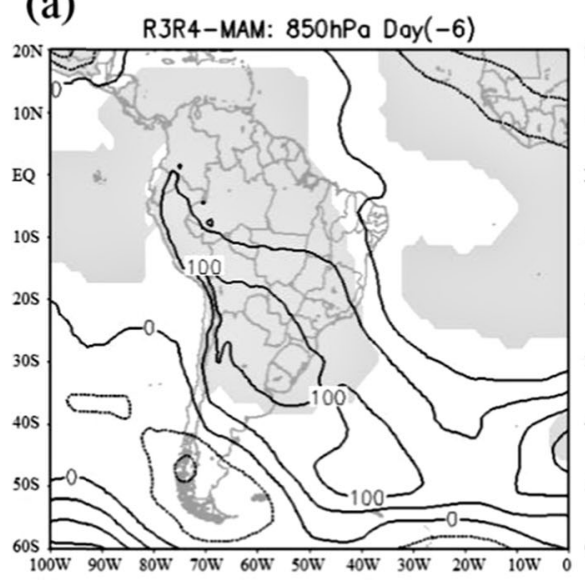

(b)

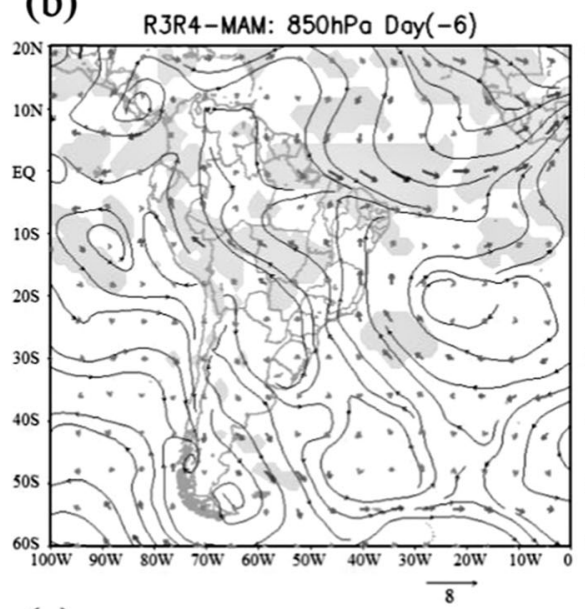

(c)

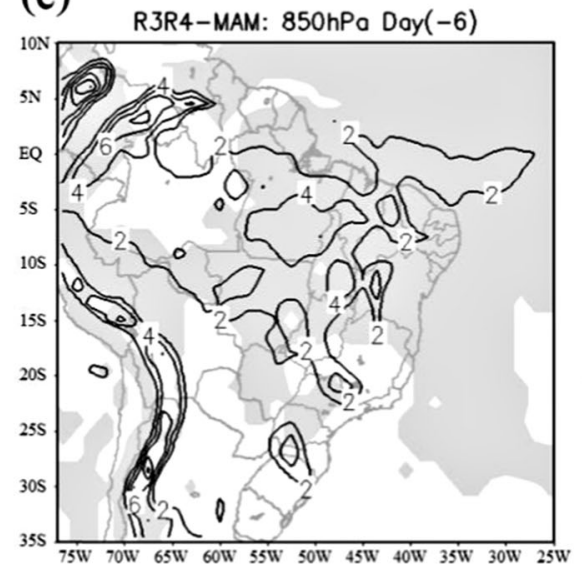

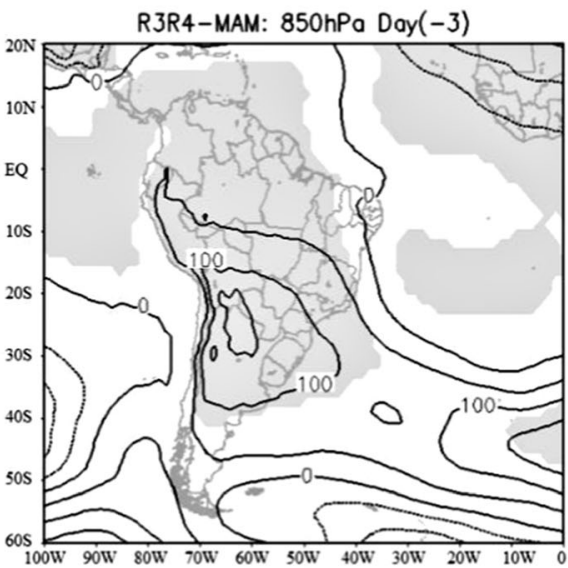

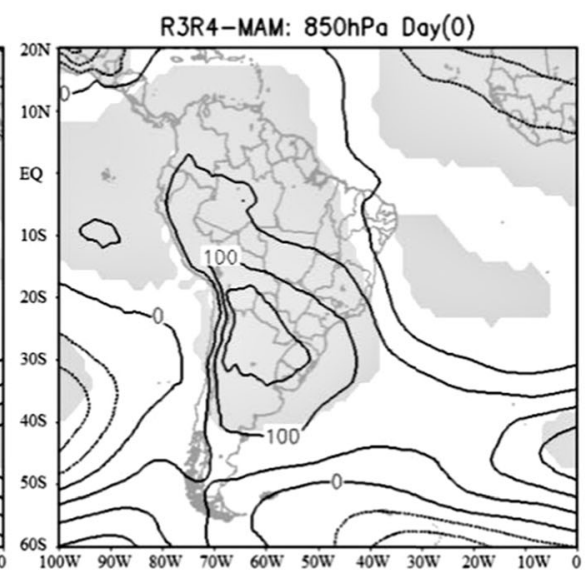

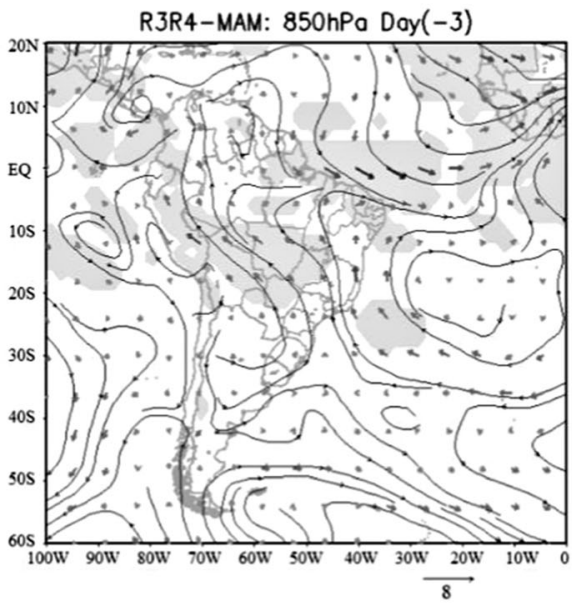
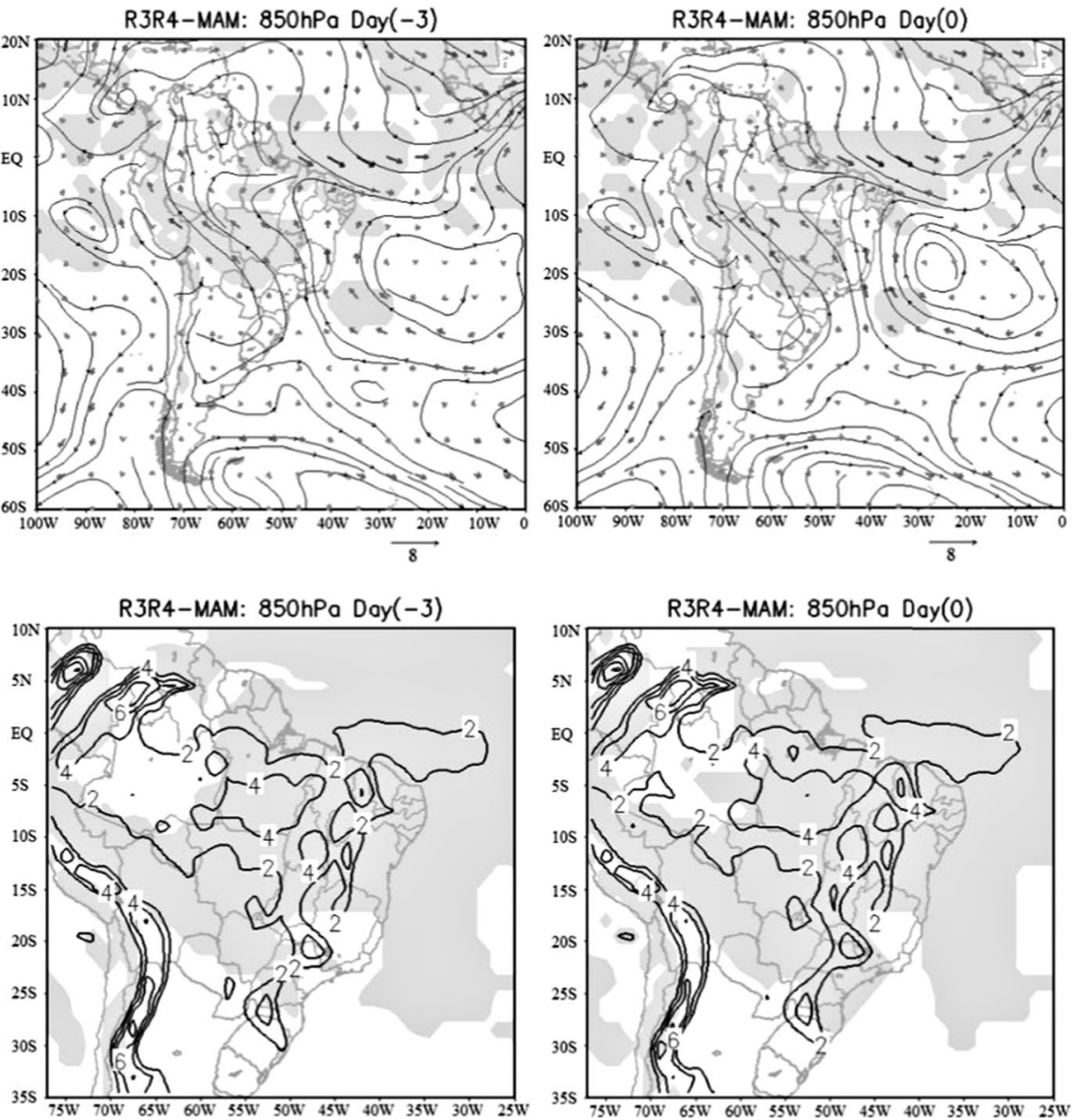

Fig. 4 Composition of anomalies for the coast of the Amazon region at $850 \mathrm{hPa}$, in the austral autumn (MAM), for $\mathrm{D}(-6), \mathrm{D}(-3)$, and $\mathrm{D}(0)$ : a geopotential anomalies (gpm, interval of $50 \mathrm{gpm})$; $\mathbf{b}$ current lines and

vector winds anomalies; c Moisture convergence $\left(10^{5} \mathrm{~g} / \mathrm{kg} . \mathrm{s}\right)$. The shaded areas are significant at the level of confidence of $95 \%$ 
the presence of the SACZ. Anagnostou and Morales (2002); Carvalho et al. (2002); Herdies et al. (2002); Laurent et al. (2002), and Rickenbach et al. (2002) pointed out that the circulation at low levels is distinguished in the southwestern part of the Amazon by a marked difference concerning wind direction-coming from the west during the $\mathrm{SACZ}$ and from the east when the SACZ is absent. According to Herdies et al. (2002), the wind anomalies at $850 \mathrm{hPa}$ in South America and the neighboring oceans, represent practically reversed circulations with respect to the rainy season means during the SACZ and non-SACZ periods. In this sense, the (a)

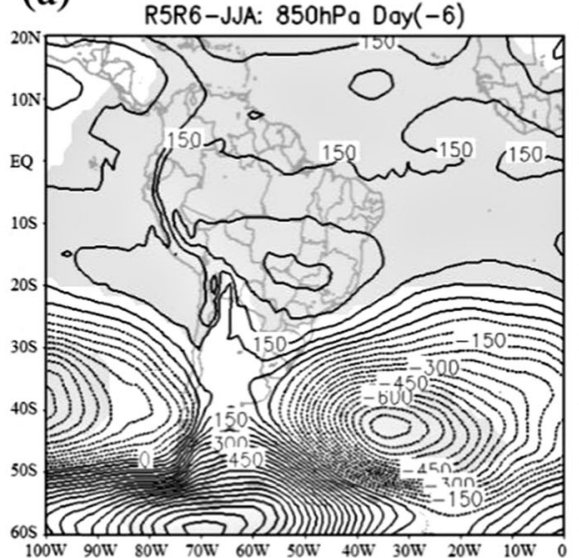

(b)

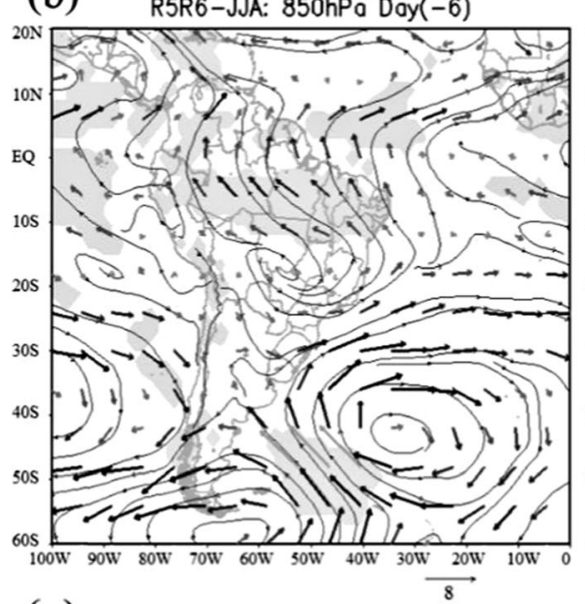

(c)

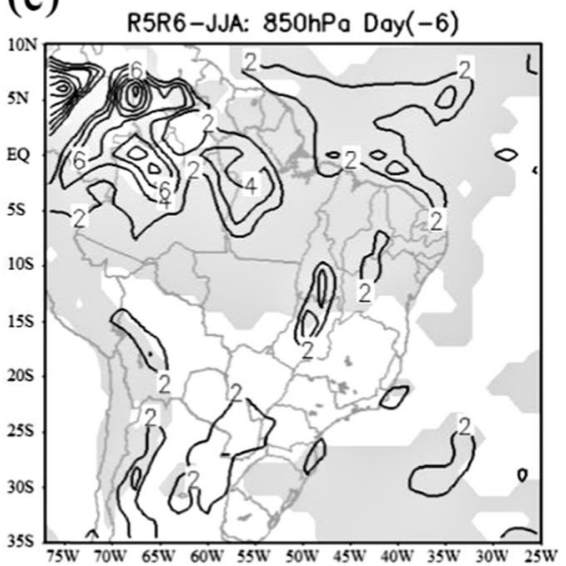

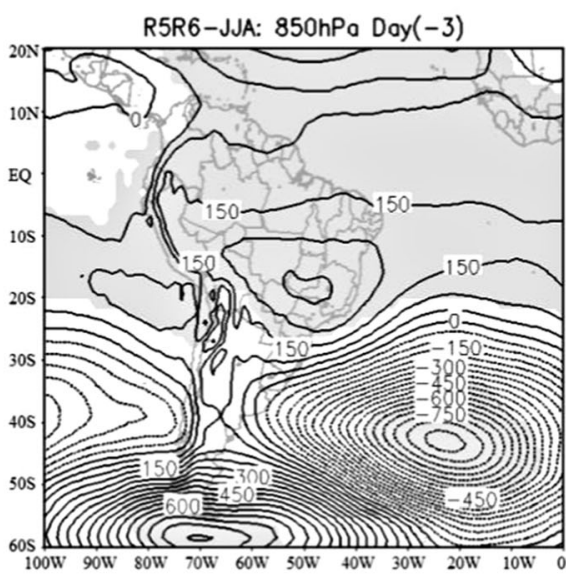

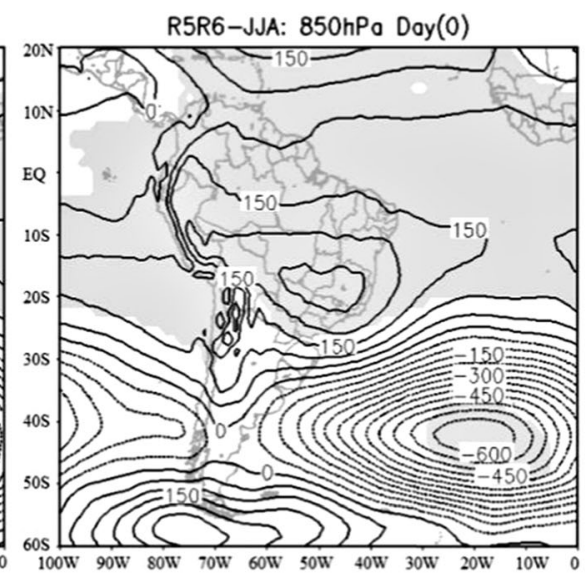

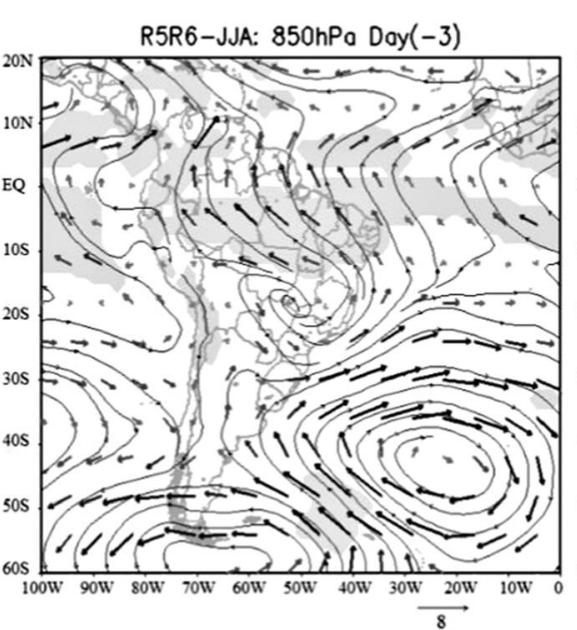
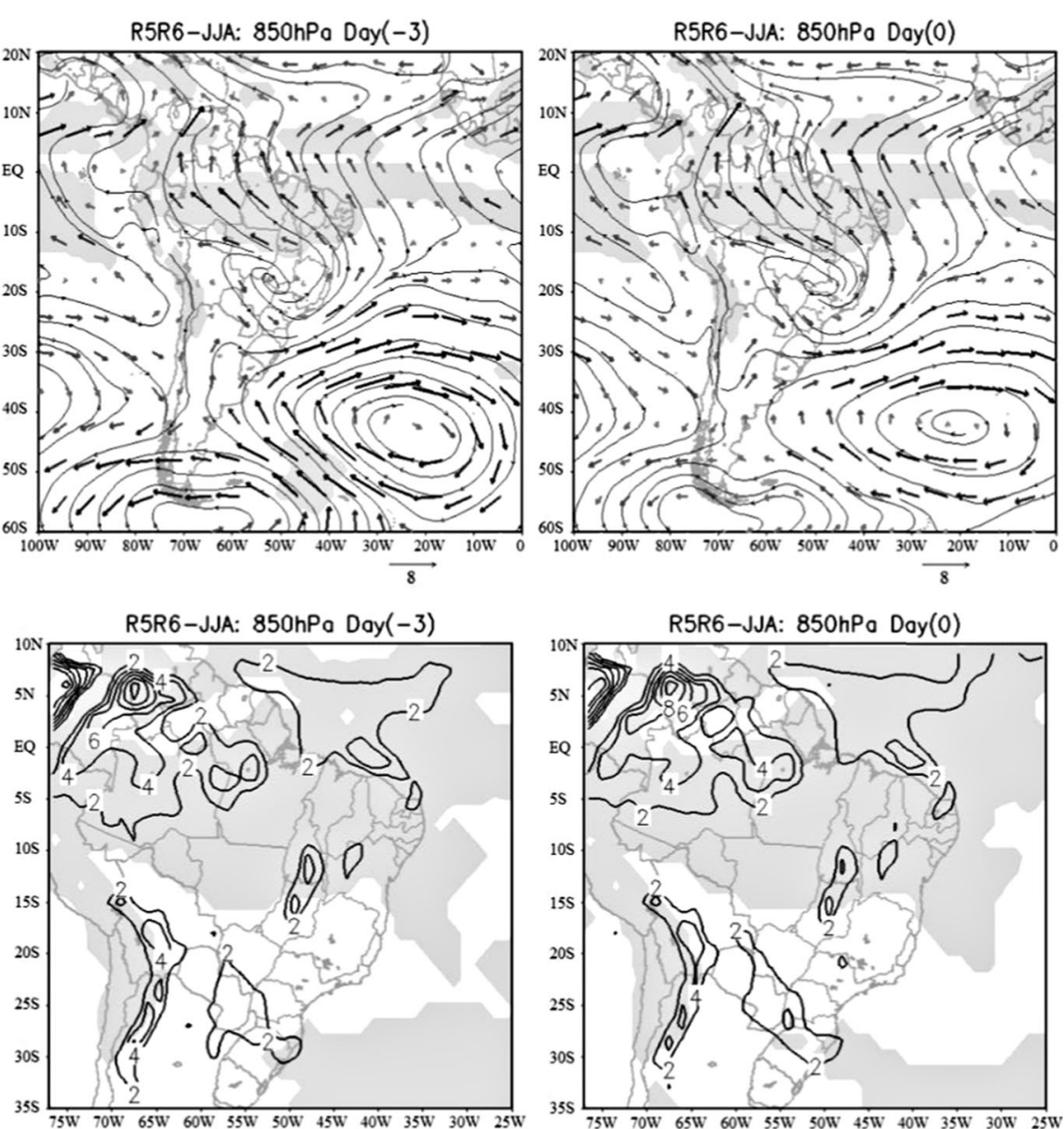

Fig. 5 Composition of anomalies for the northwest of the Amazon region of the Amazon at $850 \mathrm{hPa}$, in the austral winter (JJA), for $\mathrm{D}(-6)$, $\mathrm{D}(-3)$, and $\mathrm{D}(0)$ : a geopotential anomalies (gpm, interval of $50 \mathrm{gpm})$; $\mathbf{b}$

current lines and vector winds anomalies; c moisture convergence $\left(10^{5} \mathrm{~g} /\right.$ $\mathrm{kg} / \mathrm{s}$ ). The shaded areas are significant at the level of confidence of $95 \%$ 
South American Monsoon System (SAMS) plays an important role in the moisture transport to the Central region of South America and in the formation of the SACZ (Grimm 2011).

In the area of the northeast trade winds, significant anomalies were also found (Fig. 3b) that represent an important equatorial circulation pattern in the austral summer. The trade winds carry moisture from the Tropical Atlantic to the Amazon, associated with a higher atmospheric pressure in the Northern Tropical Atlantic.

In Fig. 3c, the moisture convergence at low levels of the Amazon toward the Subtropical Atlantic Ocean is visible, along the region of the SACZ.

In Fig. 3c, the moisture convergence at low levels of the Amazon toward the Subtropical Atlantic Ocean is visible, along the region of the $\mathrm{SACZ}$, with values between 2 and $610^{5} \mathrm{~g} / \mathrm{kg} / \mathrm{s}$ from $\mathrm{D}(-6)$ to $\mathrm{D}(0)$. Although these characteristics related to the SACZ are observed in all austral summer, variations in spatial organization and circulation are important. These variations are often responsible for rainfall intensity and the occurrence of extreme events (Carvalho and Jones 2009).

In the anomaly fields of geopotential at $850 \mathrm{hPa}$, for the 74 IPE that occurred over the coast of the Amazon (Fig. 4a) in MAM, a large area with significant positive anomalies was found positioned in the center/south of South America, with values of up to $100 \mathrm{gpm}$ at $\mathrm{D}(-6)$ and reaching $200 \mathrm{gpm}$ at $\mathrm{D}(0)$.

In Fig. $4 \mathrm{~b}$, the wind vector anomalies were low for the IPE of the Amazon coast. The largest wind vector anomalies (significant at $5 \%$ ) were found on the north coast of Brazil, with spread to the east, suggesting a weakening of the winds from the east. These IPE could therefore be related with CSL, which do not propagate to the heartland of the continent. Possibly, the CSL that caused these IPE were influenced by large-scale synoptic systems, such as the ITCZ, which is considered to be the most important (a)

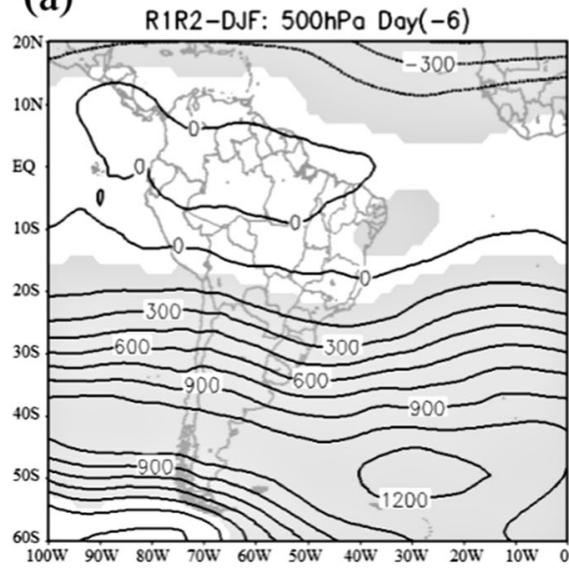

R1R2-DJF: 500hPo Doy (-3)

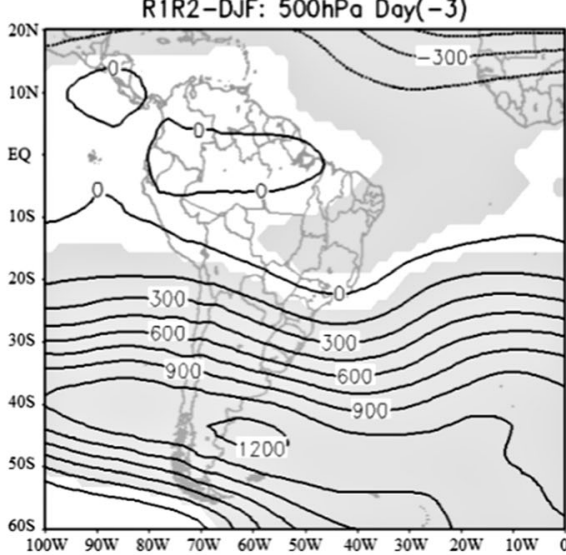

R1R2-DJF: 500hPa Day(0)

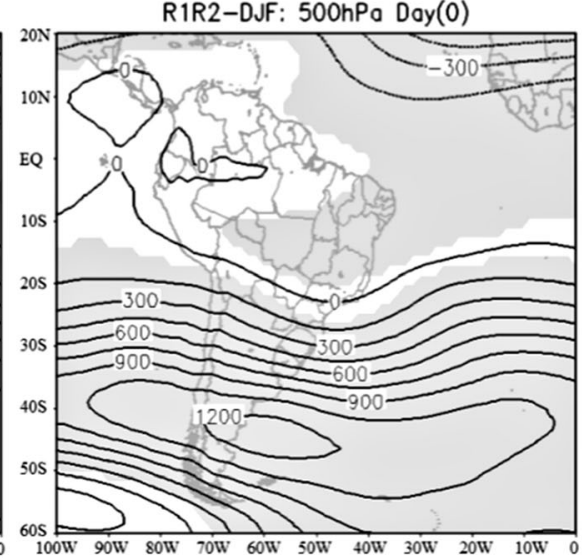

(b)
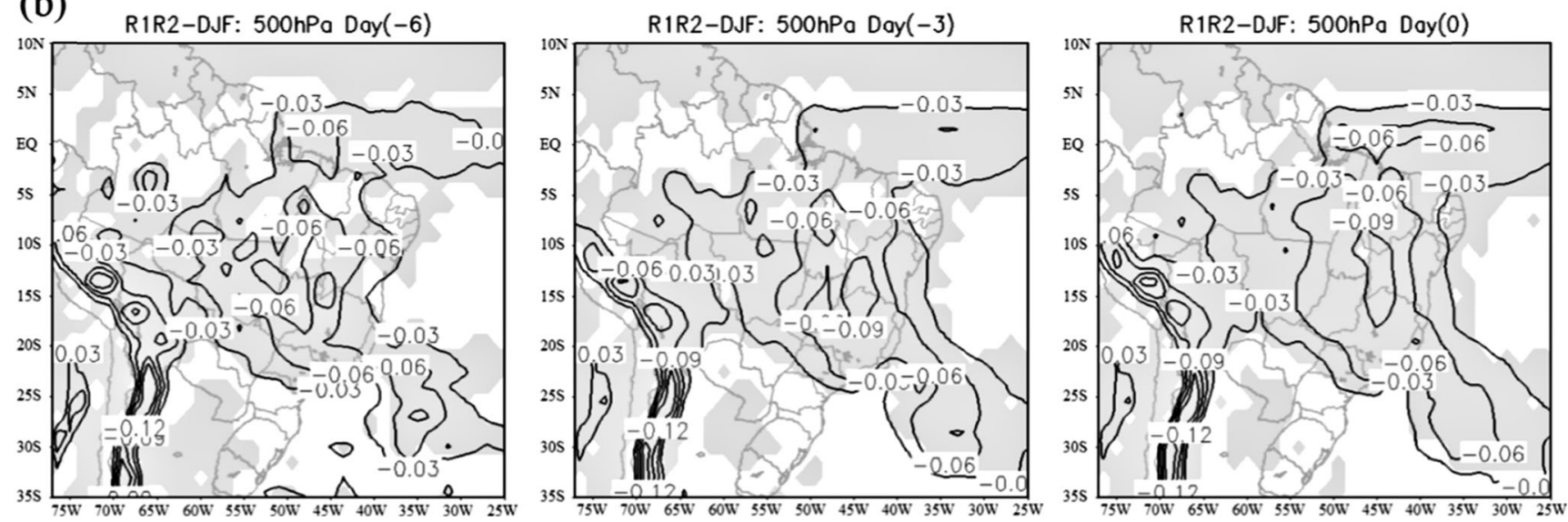

Fig. 6 Composition of anomalies for the south of the Amazon at $500 \mathrm{hPa}$, in the austral summer (DJF), for $\mathrm{D}(-6), \mathrm{D}(-3)$, and $\mathrm{D}(0)$ : a anomalies $(\mathrm{Pa} / \mathrm{s}$, interval of $0.03 \mathrm{~Pa} / \mathrm{s})$. The shaded areas are significant at the level of confidence of $95 \%$ 
generator of precipitation over the equatorial region (Reboita et al. 2010), reaching its southernmost position (around $2^{\circ} \mathrm{S}$ ) during March-April, months of the season (MAM) with the largest quantity of IPE along the coast. The CSL accompany this latitudinal displacement of the ITCZ (Cavalcanti 1982).

Low-level humidity is an important factor for the formation of CSL, and in the composition of the divergence of the moisture stream (Fig. 4c), gets visible that there is convergence in almost the entire Amazon and along the coast. This convergence is a function of the moisture transport carried out by trade winds, bringing moisture from the Atlantic Ocean to the continent.

In the northwest of the Amazon, the anomaly fields of the composition were performed for the 11 IPE cases found in the austral winter (JJA). In the composition for the geopotential at $850 \mathrm{hPa}$ (Fig. 5a), significant positive anomalies were found under the influence of an anomalous anticyclonic circulation (Fig. 5b), positioned in the center of South America. Well-defined intense negative anomalies were also observed in the geopotential (Fig. 5a) from $\mathrm{D}(-6)$ to $\mathrm{D}(0)$, with anomalous cyclonic circulation (Fig. 5b). In the composition of the wind, however, this circulation is not significant, and in the geopotential, it's only significant in the center, which is located around $35^{\circ} \mathrm{W}$ and $38^{\circ} \mathrm{S}$ at $\mathrm{D}(-6)$ with spread to the east, and around $15^{\circ} \mathrm{W}$ and $38^{\circ} \mathrm{S}$ at $\mathrm{D}(0)$.

The maximum precipitation in northwest Amazonia can be explained in terms of the condensation of moist air transported by the trade winds and lifted due to the influence of the Andes (Nobre et al. 1991, Garreaud and Wallace 1997, Da Rocha et al. 2009). This explains the strong convergence found in this region (Fig. 5(c)).

It is worth pointing out that the number of IPE cases has large impacts on the distinctiveness of the maps. In the composition with higher number of cases, the signals are smoothed compared to lower case numbers. When the number of cases is very low, if there is a (a)
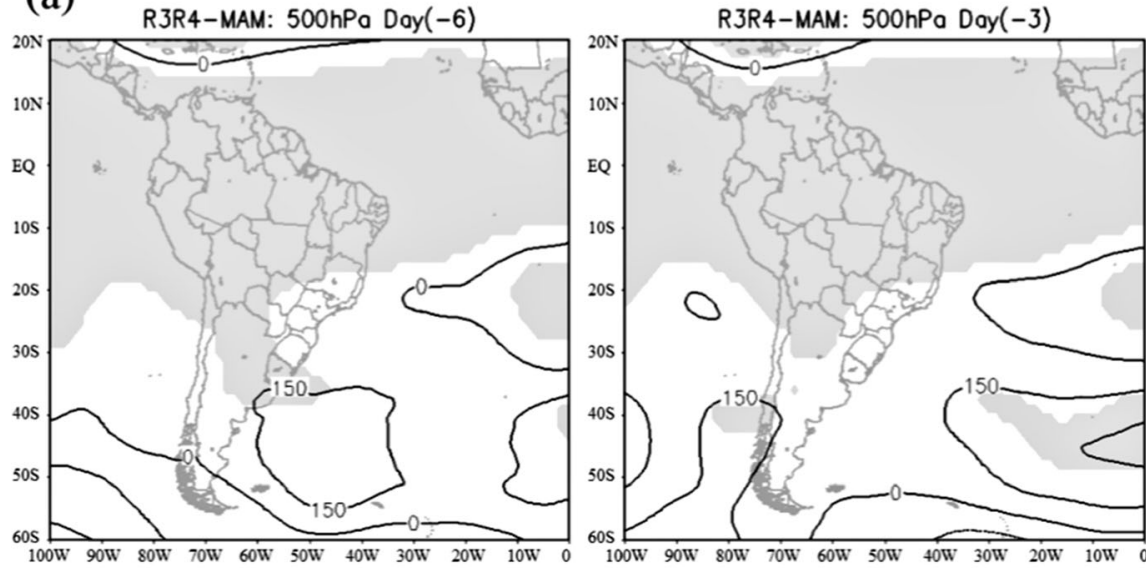

R3R4-MAM: 500hPa Day(0)

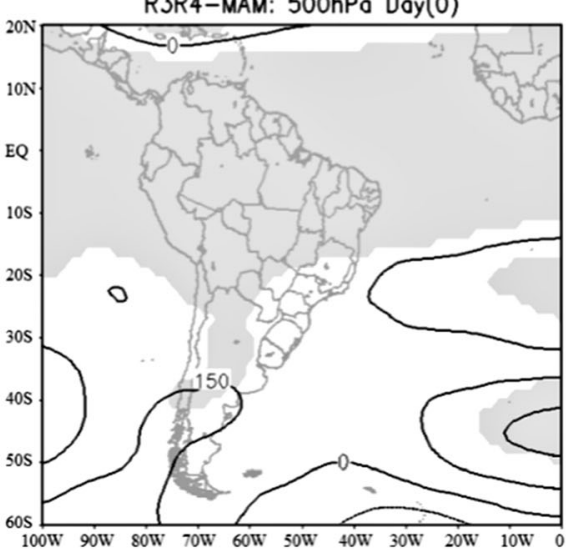

(b)
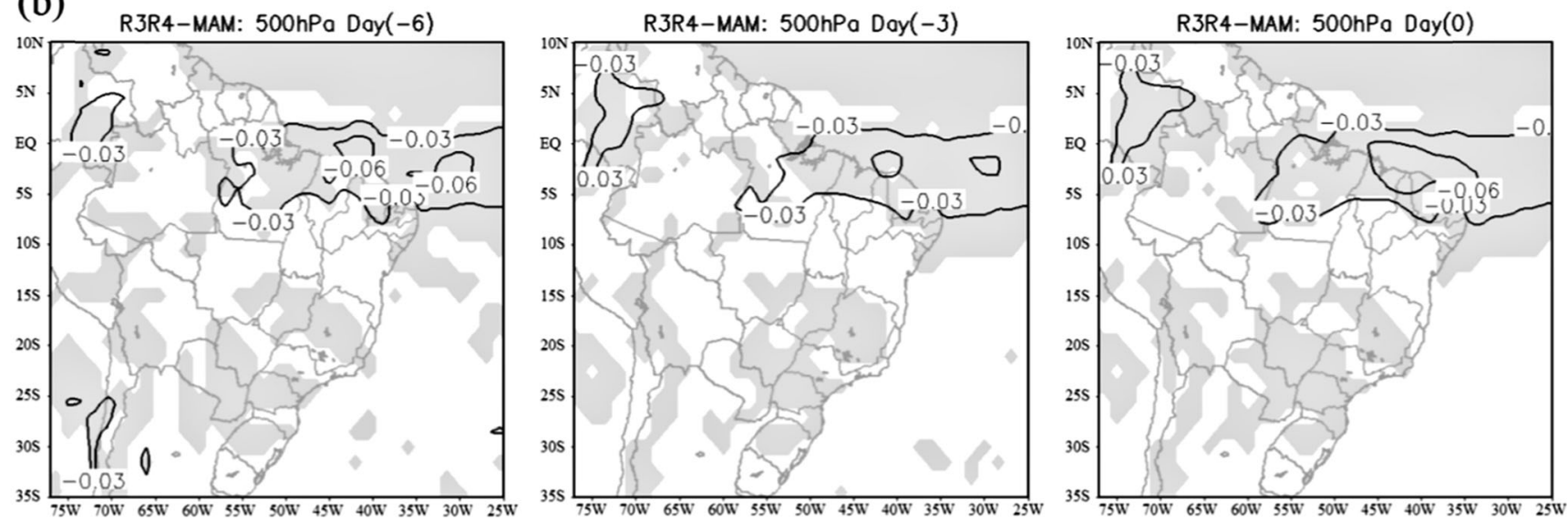

Fig. 7 Composition of anomalies for the coast of the Amazon at $500 \mathrm{hPa}$, in the austral autumn (MAM), for $\mathrm{D}(-6), \mathrm{D}(-3)$, and $\mathrm{D}(0)$ : a geopotential interval of $0.03 \mathrm{~Pa} / \mathrm{s})$. The shaded areas are significant at the level of anomalies (gpm, interval of $150 \mathrm{gpm})$ and $\mathbf{b}$ omega anomalies $(\mathrm{Pa} / \mathrm{s}$, 
certain degree of randomness, it will not be possible to check the atmospheric patterns.

\subsection{Atmospheric characteristics at medium levels}

The analysis of $500 \mathrm{hPa}$ geopotential has the important function to drive and guide the weather systems that act at the surface. In the Amazon region, however, a significant gradient in the geopotential field at $500 \mathrm{hPa}$ is hard to find. The rainfall over the Amazon is mainly convective. This means that high temperatures and high levels of humidity are the main forces behind the cloud formation mechanism.

Figure $6 \mathrm{a}$ illustrate that in the anomaly fields associated with the IPE in the south of the Amazon at $500 \mathrm{hPa}$, there were no anomalies of geopotential height over the Amazon region. At $\mathrm{D}(-6)$, these positive geopotential height anomalies are positioned around $30^{\circ} \mathrm{W}$ with displacement to the west, and at $\mathrm{D}(0)$ are positioned around $60^{\circ} \mathrm{W}$. In the vertical velocity anomaly fields (Fig. 6b), the region with the greatest upward movement along the area of activity of the SACZ can be seen, with values until $-0.06 \mathrm{~Pa} / \mathrm{s}$ in $\mathrm{D}(-6)$ and until $-0.09 \mathrm{~Pa} / \mathrm{s}$ in $\mathrm{D}(0)$.

For the IPE along the coast of the Amazon region, the geopotential anomalies at $500 \mathrm{hPa}$ (Fig. 7a) are not significant, which is consistent with the observed at $850 \mathrm{hPa}$ (Fig. 4a). In the vertical velocity profile at $500 \mathrm{hPa}$, negative anomalies could be seen along the north/northeast coast of South America, indicating upward vertical movements. At $\mathrm{D}(0)$, these movements cover a larger area with more intense movements $(-0.06 \mathrm{~Pa} / \mathrm{s})$, reaching the coast of the state of Maranhão (coast of the Amazon region). Just as was observed at low levels, these results also suggest that the IPE on the coast of the Amazon are caused by CSL. The CSL are characterized by having large conglomerates of cumulonimbus clouds, with a pronounced upward vertical movement in the convective region at $500 \mathrm{hPa}$. (a)
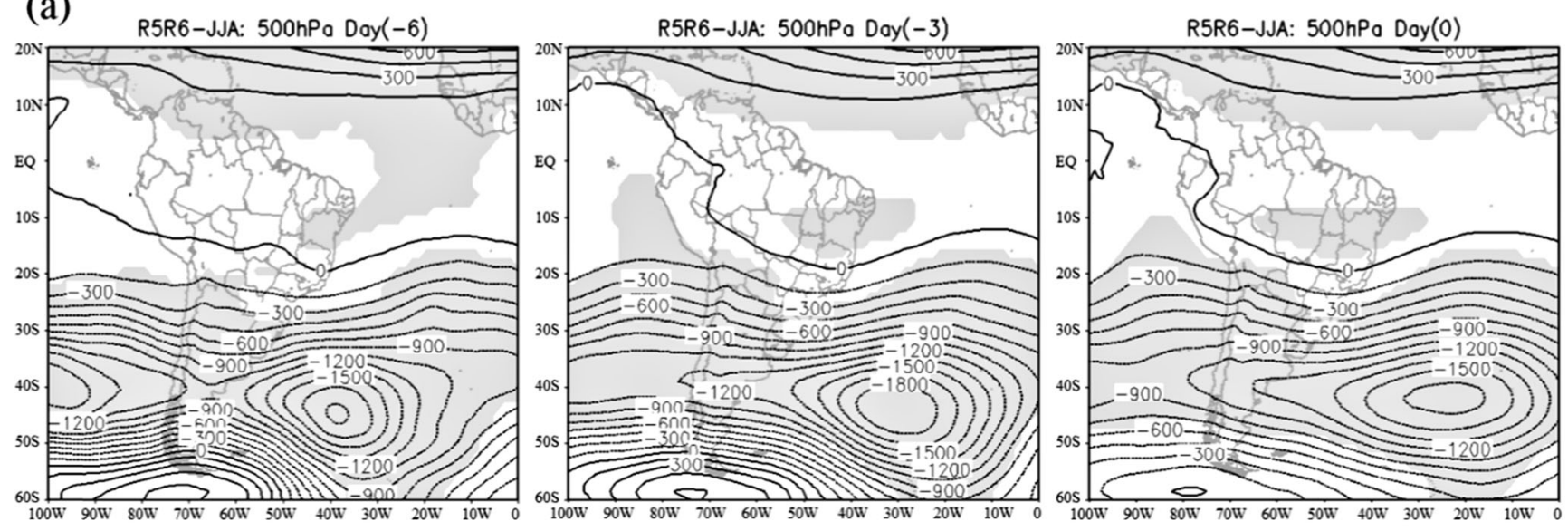

(b)
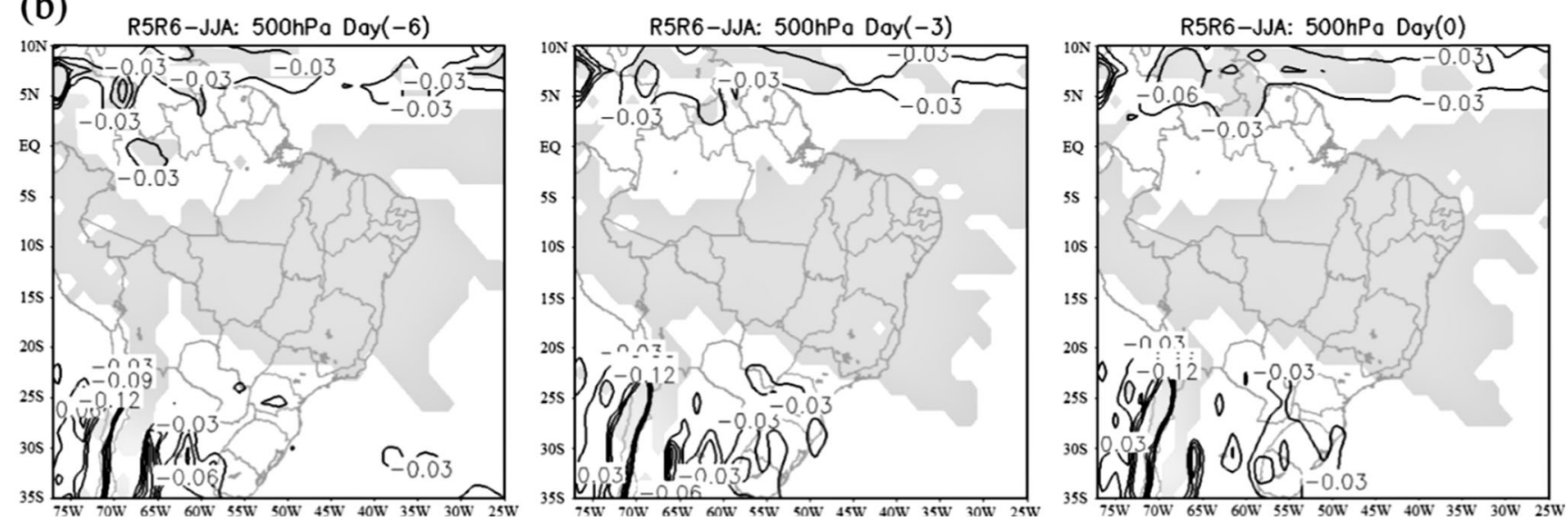

Fig. 8 Composition of anomalies for the northwest of the Amazon at $500 \mathrm{hPa}$, in the austral winter (JJA), for $\mathrm{D}(-6), \mathrm{D}(-3)$, and $\mathrm{D}(0)$ : a geopotential anomalies (gpm, interval of $150 \mathrm{gpm})$ and $\mathbf{b}$ omega anomalies $(\mathrm{Pa} / \mathrm{s}$, interval of $0.03 \mathrm{~Pa} / \mathrm{s})$. The shaded areas are significant at the level of confidence of $95 \%$ 
The anomaly fields at $500 \mathrm{hPa}$ associated with IPE in the northwest of the Amazon is presented in Fig. 8. In Fig. 8a, it's visible that no geopotential anomalies were found over the Amazon region, just as was the case in the south and along coast. The negative geopotential anomalies found over the South Atlantic at low levels (Fig. 5a), persist at $500 \mathrm{hPa}$ and are significant at $5 \%$. For the vertical velocity profile at $500 \mathrm{hPa}$, negative anomalies were found around $5^{\circ} \mathrm{N}$ and $10^{\circ} \mathrm{N}$, indicating upward vertical movements that should be associated with the ITCZ, since the ITCZ moves to the northern hemisphere in the austral winter (De Souza et al. 2005a; Broccoli et al. 2006). At D(-6), significant negative anomalies could be observed in the northwest of the State of Amazonas. At $\mathrm{D}(-3)$ and $\mathrm{D}(0)$, the significant negative anomalies are found in the northern region of the State of Roraima, with a larger area in $\mathrm{D}(0)$, with values of $-0.03 \mathrm{~Pa} / \mathrm{s}$. These results suggest that the IPE in the northwest of the Amazon are associated with the ITCZ and/or local convection.

\subsection{Atmospheric characteristics at high levels}

In the anomaly fields of the composition at $200 \mathrm{hPa}$ associated with IPE in the south of the Amazon (Fig. 9), significant negative anomalies of $-200 \mathrm{gpm}$ with a closed core (Fig. 9a) and anomalous cyclonic circulations (Fig. 9b) were found near the coast of northeast Brazil. This result is consistent with the characteristics of high-level atmospheric circulations over tropical South America in the austral summer, with a trough near the coast of the northeast of Brazil (Kousky and Gan 1981). This trough promotes the formation of highlevel cyclonic vortices (HLCV) with closed cores and a cold center, which detach themselves of the runoff and enter the continent (Kousky and Gan 1981). The presence of HLCV near the coast of the northeast would be one of the factors that influence the formation of the SACZ, because they prevent the displacement of frontal systems, making them remain semi-stationary over the southeastern coast of Brazil. (a)

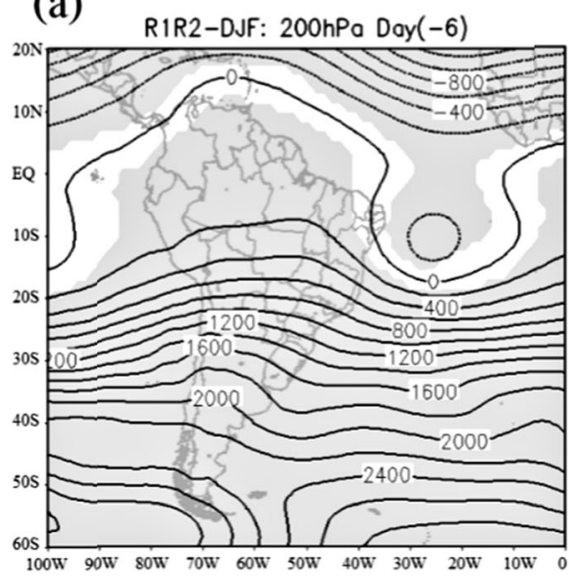

(b)

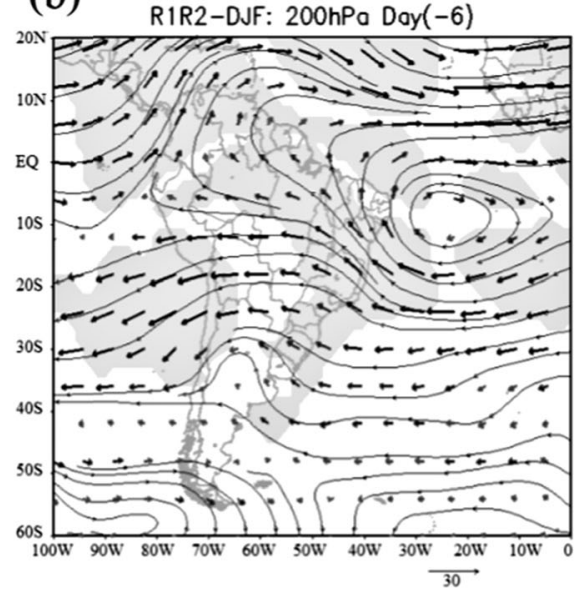

R1R2-DJF: $200 \mathrm{hPo} \operatorname{Day}(-3)$

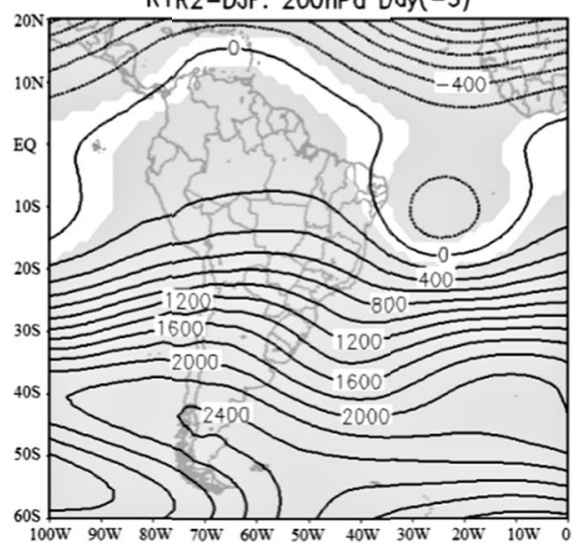

R1R2-DJF: 200hPo Doy(-3)

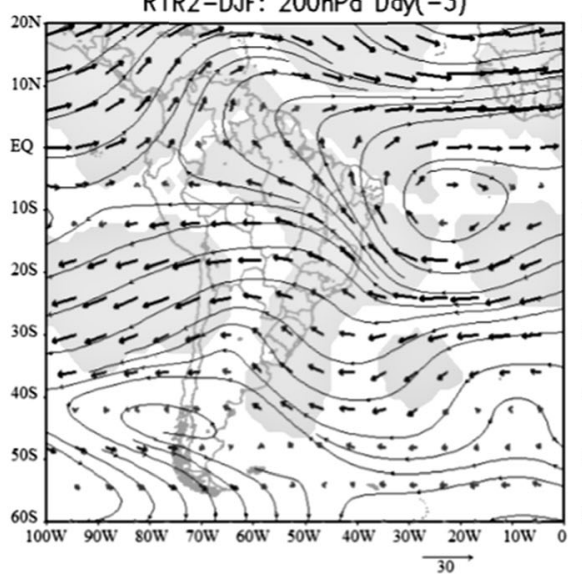

R1R2-DJF: 200hPo Day(0)

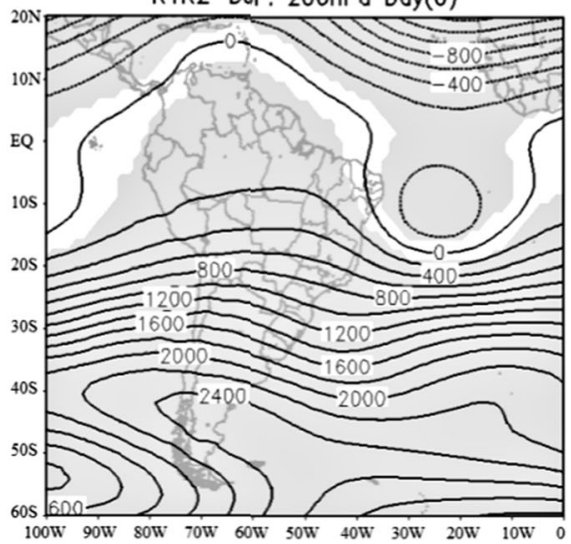

Fig. 9 Composition of anomalies for the south of the Amazon at $200 \mathrm{hPa}$, in the austral summer (DJF), for $\mathrm{D}(-6)$, D $(-3)$, and $\mathrm{D}(0)$ : a geopotential anomalies (gpm, interval of $200 \mathrm{gpm}$ ), b current lines and vector winds anomalies. The shaded areas are significant at the level of confidence of $95 \%$ 
For the wind composition anomalies at $200 \mathrm{hPa}$ (Fig. 9b) associated with IPE in the south of the Amazon, maximum negative anomalies could be observed between the latitudes $20^{\circ} \mathrm{S}$ and $30^{\circ} \mathrm{S}$, characterizing a weak subtropical jet stream (SJS). It is visible that the circulation is reversed, just as was seen at lower levels (Fig. 3b). Between the equator and $20^{\circ} \mathrm{N}$, the anomalies of the wind vector are from the west and intense, and in the southern hemisphere, the anomalies of the wind vector are from the east. This result is in line with Gan et al. (2004), who studied the changes in atmospheric circulation in South America and found inverted circulations between the dry and rainy seasons of the region. Their results show that the winds are from the east at low levels and from the west at high levels during the dry season, with the opposite occurring during the rainy season. These results are a function of the largescale circulation during the austral summer over South America associated with the monsoon regime (Zhou and Lau 1998).

In the anomaly fields at $200 \mathrm{hPa}$ (Fig. 10) associated with the IPE along the coast of the Amazon, significant positive geopotential anomalies can be observed near the coast of the northeast of Brazil, with closed core at $\mathrm{D}(-6)$. At $\mathrm{D}(0)$, significant negative anomalies of $-200 \mathrm{gpm}$ with a closed core was also found. In general, however, there were few anomalies in geopotential (Fig. 10a) and small anomalies in wind (Fig. 10b), which is in accordance with that observed at 850 and $500 \mathrm{hPa}$, suggesting that the IPE along the coast of the Amazon should be associated with mesoscale systems.

In the anomaly fields at $200 \mathrm{hPa}$ associated with the IPE in the northwest of the Amazon (Fig. 11), negative anomalies in geopotential found at $850 \mathrm{hPa}$ (Fig. 5a) and $500 \mathrm{hPa}$ (Fig. 8a) could be observed to persist until high levels, being significant at $5 \%$ (Fig. 11a). The center of this low at $\mathrm{D}(0)$ can be found at low levels around $15^{\circ} \mathrm{W}$ and at high levels around $25^{\circ} \mathrm{W}$. Regarding the wind circulation (Fig. 11b), strong anomalies can be observed between the equator and $20^{\circ} \mathrm{N}$ for the wind vector from the east, and between the latitudes $20^{\circ} \mathrm{S}$ and $30^{\circ} \mathrm{S}$ for the wind vector from (a)

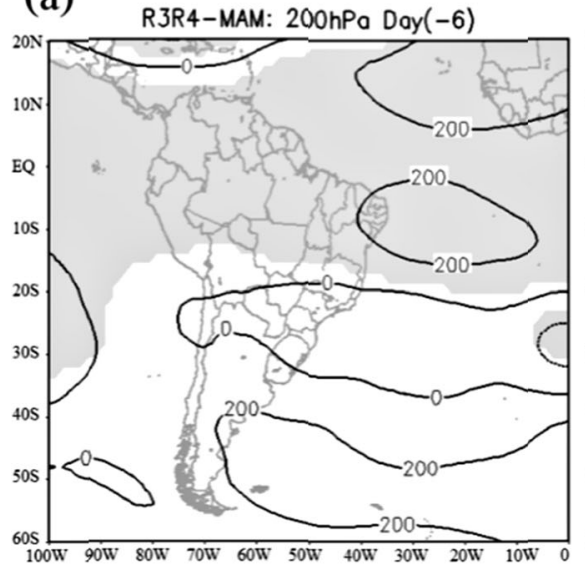

(b)

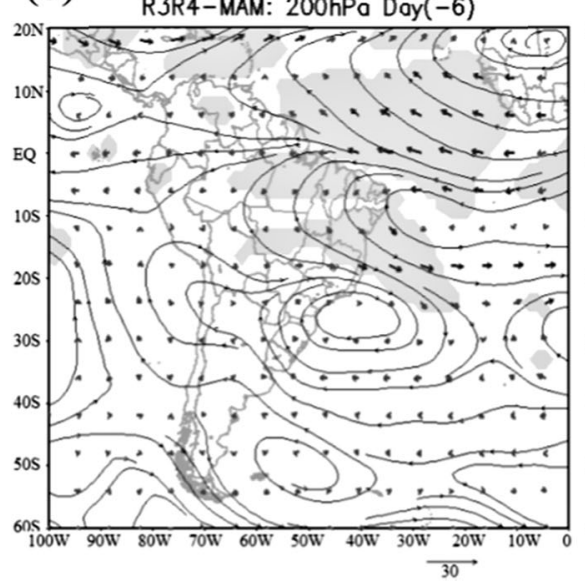

R3R4-MAM: 200hPo Day (-3)

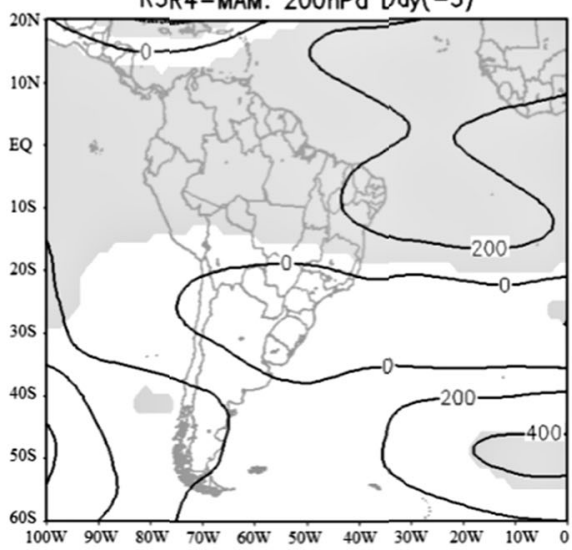

R3R4-MAM: 200hPo Doy $(-3)$

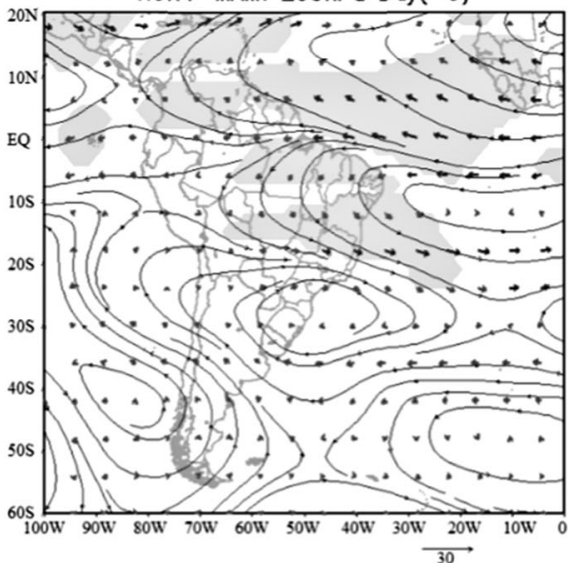

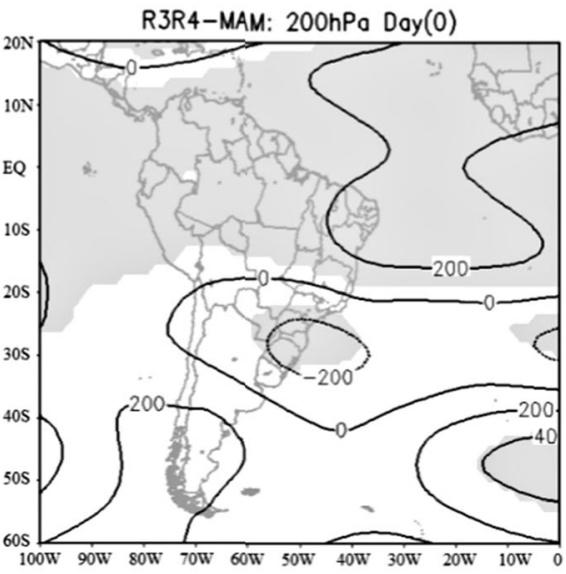

R3R4-MAM: 200hPa Day(0)

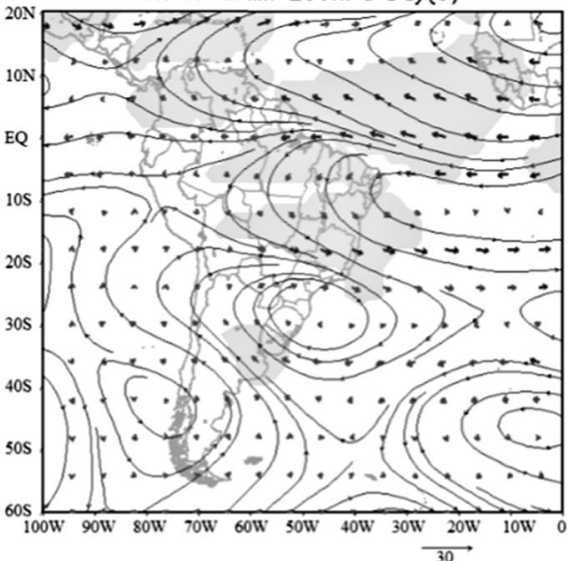

Fig. 10 Composition of anomalies for the coast of the Amazon at $200 \mathrm{hPa}$, in the austral autumn $(\mathrm{MAM})$, for $\mathrm{D}(-6)$, D( -3$)$, and $\mathrm{D}(0)$ : a geopotential anomalies (gpm, interval of $200 \mathrm{gpm}), \mathbf{b}$ current lines and vector winds anomalies. The shaded areas are significant at the level of confidence of $95 \%$ 

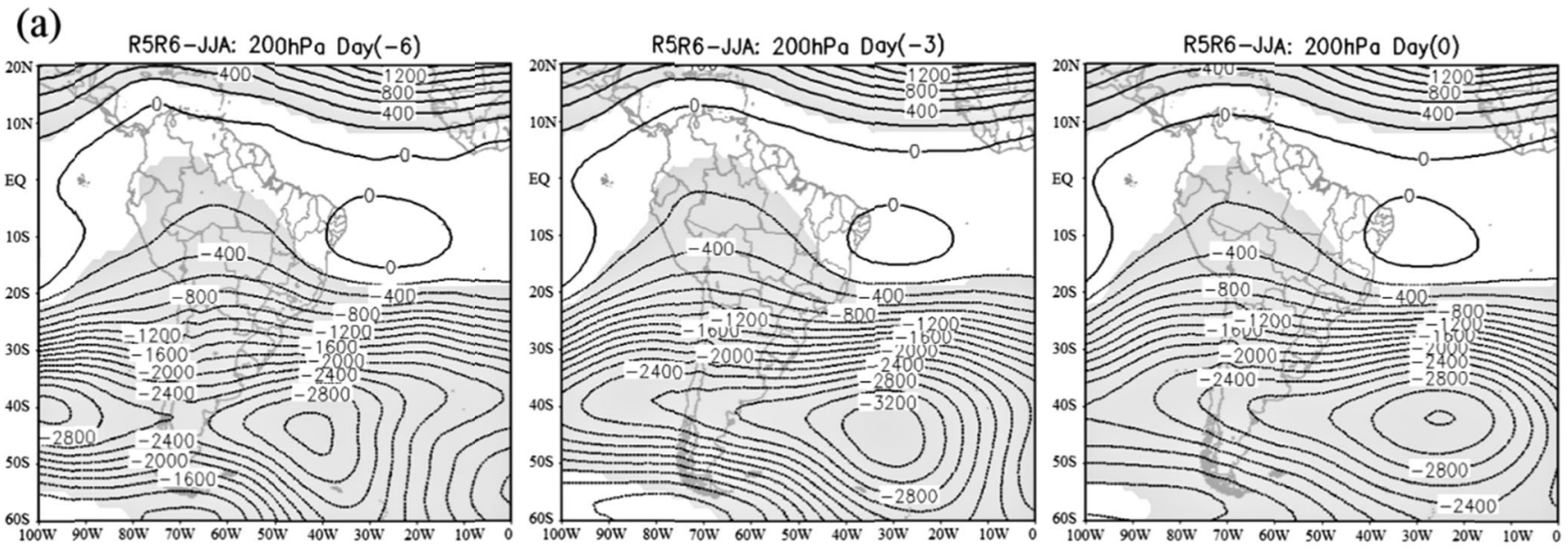

(b)
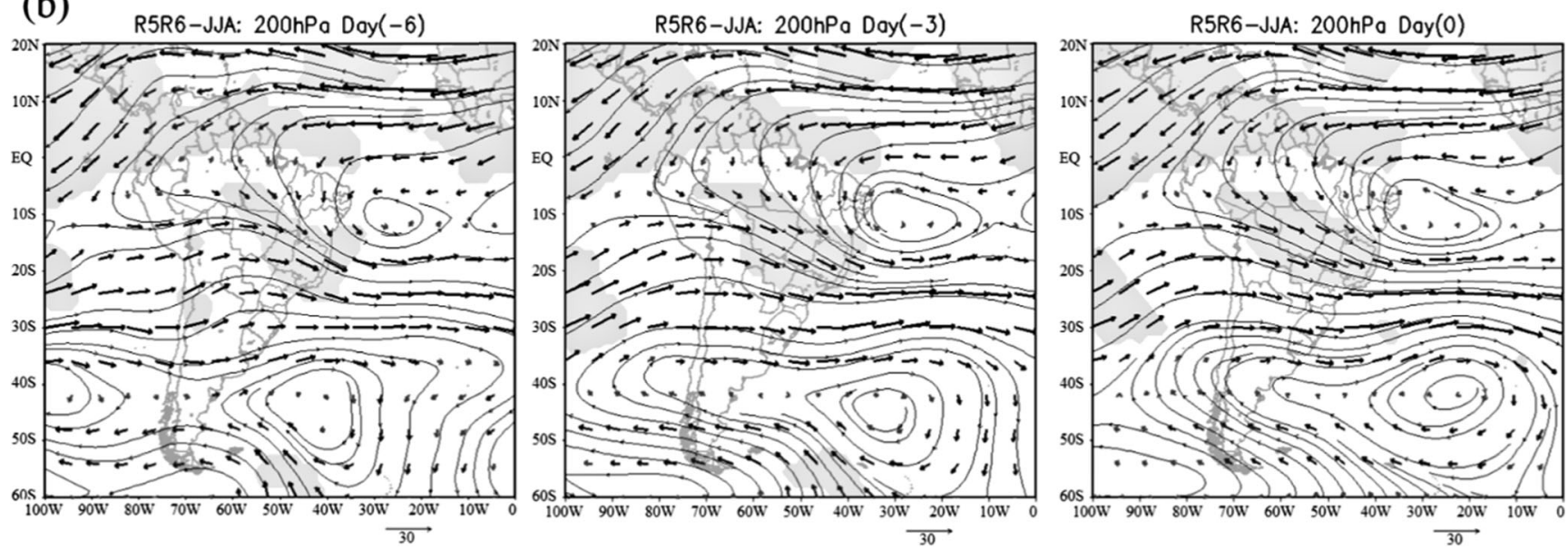

Fig. 11 Composition of anomalies for the northwest of the Amazon at $200 \mathrm{hPa}$, in the austral winter (JJA), for D( -6$)$, D( $(-3)$, and D(0): a geopotential anomalies (gpm, interval of $200 \mathrm{gpm}$ ), b current lines and vector winds anomalies. The shaded areas are significant at the level of confidence of $95 \%$

the west. These anomalies over South America are associated with the SJS. According to Palmén and Newton (1969), the Hadley circulation is one of the main mechanisms for the maintenance of the SJS. The SJS reaches its maximum intensity over South America in the austral winter, when the mean meridional circulation is most intense (Hastenrath 1991). This jet stream oscillates on average between the latitudinal range of $25^{\circ} \mathrm{S}$ and $30^{\circ}$ $\mathrm{S}$ with zonal configuration or a gentle slope from north to south, as can be seen in Fig. 11b.

\section{Conclusions}

The prevailing atmospheric pattern during the occurrence of IPE in the sub-regions of the Brazilian Amazon was revealed by applying the composition technique to the atmospheric variables: geopotential, wind, omega, and divergence of the moisture stream.
In the south of the Amazon, many of the IPE (34) occurred during the austral summer. The main characteristics associated with these IPE were the following:

i. At low levels, anomalous areas of low pressure over the South America and moisture convergence from the Amazon to the Subtropical Atlantic Ocean;

ii. At medium levels, more intense upward movement along the area associated with the SACZ activity; and

iii. At high levels, an anomalous nucleus with negative geopotential values near the coast of the northeast of Brazil.

Along the coast of the Amazon, many IPE (74) were recorded in the austral autumn, and the main characteristics found were the following:

i. At low levels, an anomalous high over South America and wind vector anomalies along the northern coast of Brazil, with propagation to the east; 
ii. At medium levels, upward vertical movements along the northern/northeastern coast of South America; and

iii. At high levels, in general, there were few anomalies in geopotential and small anomalies in wind.

In the northwest of the Amazon, the IPE occurred mostly during the austral autumn (10) and austral winter (11). The composition technique was applied to the austral winter, i.e., only 11 cases. The main characteristics found, concerning these events, were the following:

i. At low levels, an anomalous high over South America, an intense anomalous low over the South Atlantic, and strong moisture convergence in the northwest of the Amazon;

ii. At medium levels, upward vertical movements around $5^{\circ}$ $\mathrm{N}$ and $10^{\circ} \mathrm{N}$, reaching the northern part of the State of Roraima, and the persistence of the intense anomalous low in the South Atlantic, which was found at the three levels; and

iii. At high levels, the persistence of the negative anomalies in geopotential in the South Atlantic, and wind anomalies between the equator and $20^{\circ} \mathrm{N}$ for the wind vector from the east, and between the latitudes $20^{\circ} \mathrm{S}$ and $30^{\circ} \mathrm{S}$ for the wind vector from the west.

In general, there were small differences in atmospheric pattern between the day of the event $\mathrm{D}(0)$ and three $\mathrm{D}(-3)$ and six $\mathrm{D}(-6)$ preceding days. However, anomalies are intensified D-6 to D0.

This study may contribute in monitoring or tracking the Amazonian weather and climate. However, the conditions for the formation and development of the weather systems, especially in this region, are too complex. Several factors may interfere, as large-scale events, local conditions, and thermodynamic factors. Therefore, a more detailed study about weather systems that affect the rainfall in the Amazon is still necessary.

\section{References}

Alcântara CR, Silva Dias MAF, Souza EP, Cohen JCP (2011) Verification of the role of the low level jets in amazon squall lines. Atmos Res 100:36-44. doi:10.1016/j.atmosres.2010.12.023

Anagnostou EN, Morales CA (2002) Rainfall estimation from TOGA radar observations during LBA field campaign. J Geophys Res 107(D20):35.1-35.14

Broccoli AJ, Dahl KA, Stouffer RJ (2006) Response of the ITCZ to northern hemisphere cooling. Geophyssical Research Letters 33: L01702. doi:10.1029/2005GL024546

Carvalho LMV, Jones C (2009) Zona de Convergência do Atlântico Sul. In Tempo e Clima no Brasil. Cavalcanti IFA, Ferreira NJ, Silva MGAJ, Silva Dias MAF (org.). São Paulo: Oficina de Textos, 95109.
Carvalho LMV, Jones C, Liebmann B (2004) The South Atlantic Convergence Zone: intensity, form, persistence, and relationships with intraseasonal to interannual activity and extreme rainfall. $\mathrm{J}$ Clim 17:88-108. doi:10.1175/1520-0442(2004) 017<0088:TSACZI>2.0.CO;2

Carvalho LMV, Jones C, Silva Dias MAF (2002) Intraseasonal largescale circulations and mesoscale convective activity in tropical South America during the TRMM-LBA campaign. J Geophysical Res 107(D20):LBA 9-1-LBA 9-20. doi:10.1029/2001JD000745

Cavalcanti IFA (1982) Um estudo sobre interações entre sistemas de circulação de escala sinótica e circulações locais. São José dos Campos, INPE - 2494 - TDL/097.

Chen B, Lin X, Bacmeister JT (2008) Frequency distribution of daily ITCZ patterns over the western-central Pacific. J Clim 21:42074222. doi:10.1175/2008JCLI1973.1

Cohen JCP, Silva Dias MAF, Nobre CA (1995) Environmental conditions associated with Amazonian squall lines: a case study. Mon Weather Rev 123:3163-3174. doi:10.1175/1520-0493(1995) $123<3163$ :ECAWAS $>2.0$. CO; 2

Curtis SE, Hastenrath S (1999) Trends of upper-air circulation and water vapour over equatorial South America and adjacent oceans. Int $\mathbf{J}$ Climatol 19:863-876

Da Rocha RP, Morales CA, Cuadra SV, Ambrizzi T (2009) Precipitation diurnal cycle and summer climatology assessment over South America: an evaluation of regional climate model version 3 simulations. J Geophys Res 114:D10108. doi:10.1029/2008JD010212

De Oliveira VS, Satyamurty P, Andreoli RV (2013) On the South Atlantic Convergence Zone affecting southern Amazonia in austral summer. Atmos Sci Lett 14:1-6. doi:10.1002/asl.401

De Souza EB, Rocha EJP (2006) Diurnal variations of rainfall in Bragança-PA (eastern Amazon) during rainy season: mean characteristics and extreme events. Revista Brasileira de Meteorologia 21(3):142-152

De Souza EB, Kayano MT, Ambrizzi T (2005a) Intraseasonal and submonthly variability over the eastern Amazon and northeast Brazil during the autumn rainy season. Theor Appl Climatol 81: 177-191. doi:10.1007/s00704-004-0081-4

De Souza EB, Kayano MT, Ambrizzi T (2005b) Intraseasonal and submonthly variability over the eastern Amazon and northeast Brazil during the autumn rainy season. Theor Appl Climatol 81: 177-191. doi:10.1007/s00704-004-0081-4

De Souza EB, Kayano MT, Tota J, Pezzi L, Fisch G, Nobre C (2000) On the influences of the El Niño, La Niña, and Atlantic dipole pattern on the Amazonian rainfall during 1960-1998. Acta Amazônica 30(2): 305-318

de Quadro MFL, Silva Dias MAF, Herdies DL, de Goncalves LGG (2012) Análise climatológica da precipitação e do transporte de umidade na região da ZCAS através da nova geração de reanálises. Revista Brasileira de Meteorologia 27(2):152-162. doi: 10.1590/S0102-77862012000200004

De Souza EB, Lopes MNG, Da Rocha EJP, De Souza JRS, Da Cunha AC, Da Silva RR, Ferreira DBS, Santos DM, Do Carmo AMC, De Sousa JRA, Guimarães PL, Da Mota MAS, Makino M, Senna RC, Sousa AML, Mota GV, Kuhn PAF, de Souza PFS, Vitorino MI (2009) Precipitação sazonal sobre a Amazônia oriental no período chuvoso: observações e simulações regionais com o RegCM3. Revista Brasileira de Meteorologia 24(2):111-124. doi:10.1590/ S0102-77862009000200001

Dee DP, Uppala SM, Simmons AJ, Berrisford P, Poli P, Kobayashi S, Andrae U, Balmaseda MA, Balsamo G, Bauer P, Bechtold P, Beljaars ACM, Van de Berg L, Bidlot J, Bormann N, Delsol C, Dragani R, Fuentes M, Geer AJ, Haimberger L, Healy SB, Hersbach H, Hólm EV, Isaksen L, Kallberg P, Köhler M, Matricardi M, Mcnally AP, Monge-sanz BM, Morcrette JJ, Park BK, Peubey C, De Rosnay P, Tavolato C, Thépaut JN, Vitart F 
(2011) The era-interim reanalysis: configuration and performance of the data assimilation system. Q J R Meteorol Soc 137:553-597

Espinoza JC, Lengaigne M, Ronchail J, Janicot S (2012) Large-scale circulation patterns and related rainfall in the Amazon basin: a neuronal networks approach. Clim Dyn 38(1-2):121-140. doi:10.1007/ s00382-011-1010-8

Espinoza JC, Marengo JA, Ronchail J, Molina J, Noriega L, Guyot JL (2014) The extreme 2014 flood in south-western Amazon basin: the role of tropical-subtropical south Atlantic SST gradient. Environ Res Lett 9:124007. doi:10.1088/1748-9326/9/12/124007

Espinoza JC, Ronchail J, Frappart F, Lavado W, Santini W, Guyot JL (2013) The major floods in the Amazonas river and tributaries (Western Amazon Basin) during the 1970-2012 period: a focus on the 2012 flood. Journal of Hydrometeorology 14(3):1000-1008. doi:10.1175/JHM-D-12-0100.1

Espinoza JC, Ronchail J, Guyot JL, Junquas C, Vauchel P, Lavado W, Drapeau G, Pombosa R (2011) Climate variability and extreme drought in the upper Solimões River (western Amazon basin): understanding the exceptional 2010 drought. Geophys Res Lett 38(13):L13406. doi:10.1029/2011GL047862

Gan MA, Kousky VE (1986) Vórtices ciclônicos da Alta troposfera no oceano atlântico Sul. Revista Brasileira de Meteorologia 1:19-28

Gan MA, Kousky VE, Ropelewski CF (2004) The South America monsoon circulation and its relationship to rainfall over West-Central Brazil. Journal of climate 17:47-66. doi:10.1175/1520-0442(2004) 017<0047:TSAMCA >2.0.CO;2.

Garreaud RD, Wallace JM (1997) The diurnal March of convective cloudiness over the Americas. Monthly Weather Review 125:3157-3171. doi:10.1175/1520-0493(1997)125<3157:TDMOCC >2.0.CO;2.

Gemmer M, Fischer T, Jiang T, Su B, Liu LL (2011) Trends in precipitation extremes in the Zhujiang River Basin, South China. Journal of Climate 24:750-761. doi:10.1175/2010JCLI3717.1.

Grimm AM (2011) Interannual climate variability in South America: impacts on seasonal precipitation, extreme events and possible effects of climate change. Stochastic Environmental Research and Risk Assessment. 25(4):537-554. doi:10.1007/s00477-010-0420-1

Groisman PY, Knight RW, Easterling DR, Karl TR, Hegerl GC, Razuvaev VN (2005) Trends in intense precipitation in the climate record. Journal of Climate 18:1326-1350

Hastenrath S (1985) Climate and circulation of the tropics. Atmospheric Sciences Library, D. Reidel Publishing Company, $455 \mathrm{p}$.

Hastenrath S (1991) Climate dynamics of the tropics. Updated ed. from Climate and Circulation of the Tropics. Kluwer Academic Publishers. 488p.

Herdies DL, Da Silva A, Silva Dias MAF, Ferreira RN (2002) The moisture budget of the bimodal pattern of the summer circulation over South America. J Geophysical Res 107(D20):42-1-42-10

Kousky VE, Gan MA (1981) Upper tropospheric cyclonic vortices in the tropical south Atlantic. Tellus 33A:538-550

Laurent H, Machado LAT, Morales CA, Durieux L (2002) Characteristics of the Amazonian mesoscale convective systems observed from satellite and radar during the WETAMC/LBA experiment. J Geophys Res 107(D20). doi:10.1029/2001JD000337

Liebmann B, Marengo JA (2001) Interannual variability of the rainy season and rainfall in the Brazilian Amazon Basin. J Clim 14: 4308-4318. doi:10.1175/1520-0442(2001)014<4308:IVOTRS $>2$. $0 . \mathrm{CO} ; 2$

Lima KC, Satyamurty P (2010) Post-summer heavy rainfall events in southeast Brazil associated with South Atlantic Convergence Zone. Atmos Sci Lett 11:13-20. doi:10.1002/asl.246

Lima KC, Satyamurty P, Fernández JPR (2010) Large-scale atmospheric conditions associated with heavy rainfall episodes in southeast Brazil. Theor Appl Climatol 101:121-135. doi:10.1007/s00704009-0207-9

M Moura d, Vitorino MI (2012) Variabilidade da precipitação em tempo e espaço associada à zona de convergência intertropical. Revista
Brasileira de Meteorologia 27(4):475-483. doi:10.1590/S010277862012000400010

Madden RA, Julian PR (1972) Description of global-scale circulation cells in the tropics with a 40-50 days period. J Atmos Sci 29: $1109-1123$

Marengo JA, Espinoza JC (2015) Extreme seasonal droughts and floods in Amazonia: causes, trends and impacts. Int J Climatol. doi:10. $1002 /$ joc. 4420

Marengo JA, Alves LM, Soares WR, Rodriguez DA, Camargo H, Riveros MP, Pabló AD (2013a) Two contrasting severe seasonal extremes in tropical South America in 2012. Flood in Amazonia and drought in northeast Brazil. J Clim 26:91379154. doi:10.1175/JCLI-D-12-00642.1

Marengo JA, Borma LS, Rodriguez DA, Pinho P, Soares WR, Alves LM (2013b) Recent extremes of drought and flooding in Amazonia: vulnerabilities and human adaptation. American Journal of Climate Change 2(2):87-96s. doi:10.4236/ajcc. 2013.22009

Marengo JA, Tomasella J, Alves LM, Soares WR, Rodriguez DA (2011) The drought of 2010 in the context of historical droughts in the Amazon region. Geophys Res Lett 38:L12703. doi:10.1029/ 2011GL047436

Marengo JA, Tomasella J, Soares W, Alves LM, Nobre CA (2012) Extreme climatic events in the Amazon basin: climatological and hydrological context of recent floods. Theor Appl Climatol 107:7385. doi:10.1007/s00704-011-0465-1

Nobre CA, Obregón GO, Marengo JA, Fu R, Poveda G (2009) Characteristics of Amazonian climate: main features, in Amazonia and Global. American Geophysical Union, Washington D. C. 186. DOI: 10.1029/2008GM000720.

Nobre CA, Sellers PJ, Shukla J (1991) Amazonian deforestation and regional climate change. J Clim 4(10):957-988. doi:10.1175/15200442(1991)004<0957:ADARCC >2.0.CO;2

Nobre P, Shukla J (1996) Variations of sea surface temperature, wind stress, and rainfall over the tropical Atlantic and South America. Journal of Climate 9:2464-2479. doi:10.1175/1520-0442(1996) 009<2464:VOSSTW>2.0.CO;2.

Oliveira AP, Fitzjarrald DR (1993) The Amazon River breeze and the local boundary layer: I - observations. Boundarry Layer Meteorology 63:141-162. doi:10.1007/BF00705380

Oliveira PT, Lima KC, Santos e Silva CM (2013) Synoptic environment associated with heavy rainfall events on the coastland of northeast Brazil. Adv Geosci 35:73-78. doi:10.5194/adgeo-35-73-2013

Palmén E, Newton CW (1969) Atmospheric circulation systems. Academic Press, New York, p. 603

Reboita MS, Gan MA, Rocha RP, Ambrizzi T (2010) Regimes de precipitação na américa do Sul: uma revisão bibliográfica. Revista Brasileira de Meteorologia 25:185-204

Rickenbach TM, Ferreira RN, Halverson JB, Herdies DL, Silva Dias MAF (2002) Modulation of convection in the southwestern Amazon Basin by extratropical stationary fronts. J Geophys Res 107(D20). doi:10.1029/2000JD000263

Santos EB, Lucio PS, Santos e Silva CM (2014) Precipitation regionalization of the Brazilian Amazon. Atmospheric Science Letters. doi: $10.1002 /$ asl 2.535

Santos EB, Lucio PS, Santos e Silva CM (2015) Seasonal analysis of return periods for maximum daily precipitation in the Brazilian Amazon. Journal of Hydrometeorology. doi:10.1175/JHM-D-140201.1

Silva Dias MAF, Silva Dias PL, Longo M, Fitzjarrald DR, Denning AS (2004) River breeze circulation in eastern Amazonia: observations and modeling results. Theor Appl Climatol 78:111-121. doi:10. 1007/s00704-004-0047-6

Souza EB, Ambrizzi T (2003) Pentad precipitation climatology over Brazil and assssociated atmospheric mechanisms. Climanálise Boletim de Monitoramento e Análise Climática. 
Souza EB, Ambrizzi T (2006) Modulation of the intraseasonal rainfall over tropical Brazil by the Madden Julian oscillation. Int J Climatol 26(13):1759-1776. doi:10.1002/joc.1331

Zhai P, Zhang X, Wan H, Pan X (2005) Trends in total precipitation and frequency of daily precipitation extremes over
China. Journal of Climate 18:1096-1108. doi:10.1175/JCLI3318.1

Zhou J, Lau K-M (1998) Does a monsoon climate exist over South America? J Clim 11:1020-1040. doi:10.1175/1520-0442(1998) 011<1020:DAMCEO >2.0.CO;2 